Classification cenco"/o

by authority of TDD-1382 - 52

by 96

\title{
$3-3-75$
}

Exempt from CCRP Re-review Requirements (per 7/22/82 Duir/Caudugmemorandum) $3 / 3 / 0^{4}$

ELECTRON MICROSCOPY ANALYSIS

OF IRRADIATED SNAP 8 FUEL

(Title Unclassified)

AEC Research and Development Report

\section{RESTRIETED DATA}

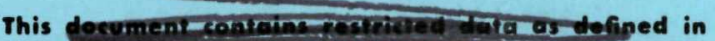

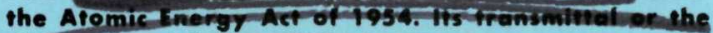

disclosure of irs conterts in am -menner to an unauthorized person is prohibited.

This doewment contains confidentiel-Restricfed Data

- celating 10 civilien-epplieations of atomic energy.

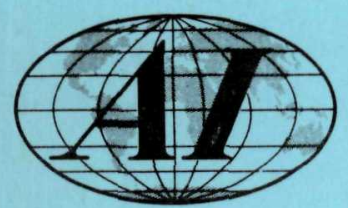

\section{कार्य I}

Exetrded fromantomatro down-

\section{ATOMICS INTERNATIONAL}

\section{A DIVISION OF NORTH AMERICAN AVIATION, INC.}




\section{DISCLAIMER}

This report was prepared as an account of work sponsored by an agency of the United States Government. Neither the United States Government nor any agency Thereof, nor any of their employees, makes any warranty, express or implied, or assumes any legal liability or responsibility for the accuracy, completeness, or usefulness of any information, apparatus, product, or process disclosed, or represents that its use would not infringe privately owned rights. Reference herein to any specific commercial product, process, or service by trade name, trademark, manufacturer, or otherwise does not necessarily constitute or imply its endorsement, recommendation, or favoring by the United States Government or any agency thereof. The views and opinions of authors expressed herein do not necessarily state or reflect those of the United States Government or any agency thereof. 


\section{DISCLAIMER}

Portions of this document may be illegible in electronic image products. Images are produced from the best available original document. 
This report was prepared as an account of Government sponsored work. Neither the United States, nor the Commission, nor any person acting on behalf of the Commission:

A. Makes any warranty or representation, express or implied, with respect to the accuracy, completeness, or usefulness of the information contained in this report, or that the use of any information, apparatus, method, or process disclosed in this report may not infringe privately owned rights; or

B. Assumes any liabilities with respect to the use of, or for damages resulting from the use of information, apporatus, method, or process disclosed in this report.

As used in the above, "person acting on behalf of the Commission" includes any employee or contractor of the Commission, or employee of such contractor, to the extent that such employee or contractor of the Commission, or employee of such controctor prepares, disseminates, or provides access to, any information pursuant to his employment or contract with the Commission, or his employment with such contractor.

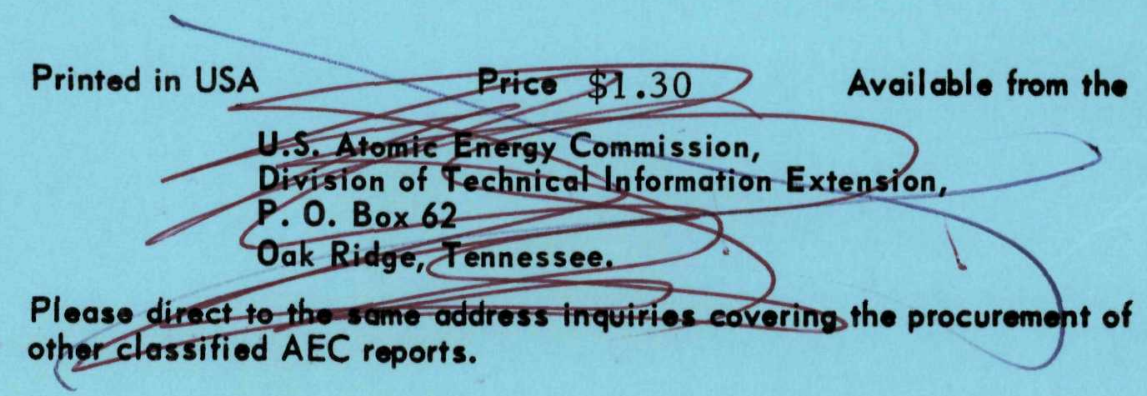


NAA-SR-12449

SNAP REACTOR, SNAP PROGRAM
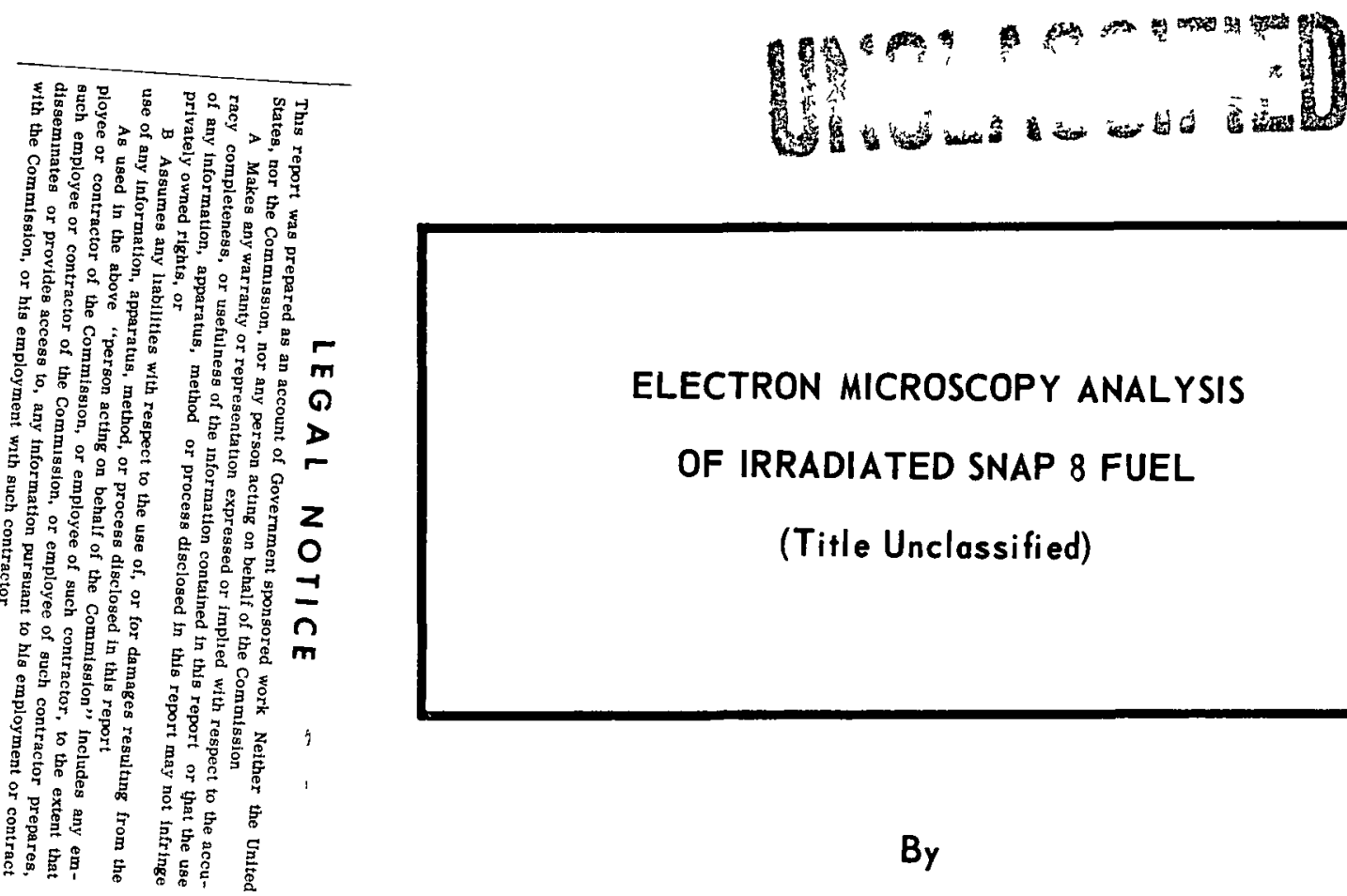

\section{ELECTRON MICROSCOPY ANALYSIS}

OF IRRADIATED SNAP \& FUEL

(Title Unclassified)

By

K. J. MILLER

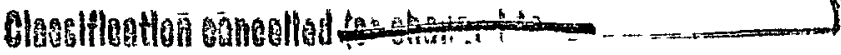

Wy antiofty or TID-1382.52

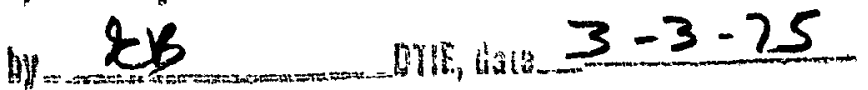

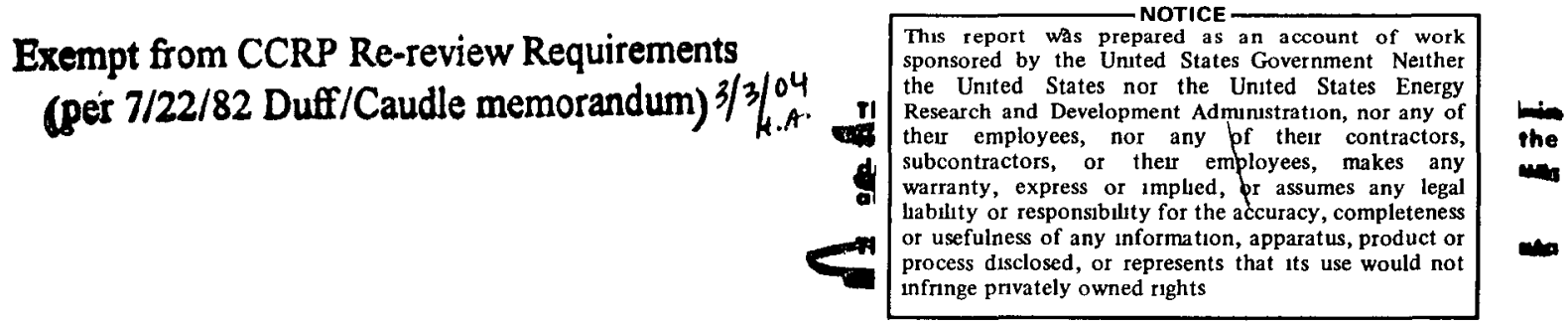

\section{ATOMICS INTERNATIONAL}
A DIVISION OF NORTH AMERICAN AVIATION, INC. P.O. BOX 309 CANOGA PARK, CALIFORNIA 


\section{DISTRIBUTION}

\section{SYSTEMS FOR NUCLEAR AUXILIARY POWER (SNAP)-REACTOR SNAP PROGRAM M-3679 (5 lst Ed.)}

No. of

Copies

AEC Albuquerque Operations Office

AEC California Patent Group

AEC Chicago Patent Group

AEC New York Operations Office

AEC Oak Ridge Operations Office

AEC Patent Office

Aerojet-General Corporation (NASA)

Aerojet-General Corporation,

Sacramento

Aerojet-General Corporation,

San Ramon (NASA)

Aerospace Corporation, Los Angeles (AF)

Air Force Aeronautical Systems

Division

Air Force Headquarters

Air Force Weapons Laboratory

Argonne National Laboratory

Army Reactors Field Group

Army White Sands Missile Range

ARO, Inc.

Battelle Memorial Institute

Battelle-Northwest

Bellcomm, Inc. (NASA)

Brookhaven National Laboratory

Central Intelligence Agency

Director of Defense Research and Engineering

Douglas Aircraft Corporation

MSSD (AF)

Du Pont Company, Aiken

Du Pont Company, Wilmington

General Atomic Division

General Dynamics/Fort Worth

General Electric Company, Cincinnati (AEC)

General Electric Company (FPD)

General Electric Company MSVD (AEC)

General Electric Company, San Jose

Institute for Defense Analyses

J et Propulsion Laboratory (NASA)

Johns Hopkins University (Navy)

Lawrence Radiation Laboratory, Livermore

Lockheed-Georgia Company

Los Alamos Scientific Laboratory
1

1

1
No. of

Copies

Martin Company

Martin Marietta Corporation,

Denver (AF)

Minnesota Mining and Manufacturing Company

Mound Laboratory

NASA Goddard Space Flight Center

NASA Lewis Research Center

NASA Manned Spacecraft Center

NASA Marshall Space Flight Center

NASA, Washington

National Reactor Testing Station (INC)

Navy Air Development Center

Navy Facilities Engineering Command

Navy Office of the Chief of Naval

Operations

Navy Ordnance Systems Command

Navy Radiological Defense Laboratory

Navy Research Laboratory

Navy Ship Systems Command

Headquarters

Oak Ridge National Laboratory (AEC)

Pratt and Whitney Aircraft Division

(NASA)

Radio Corporation of America (NY)

Radio Corporation of America,

Cranbury

Rand Corporation ( $\mathrm{AF}$ )

Republic Aviation Division

Sandia Corporation, Albuquerque (AEC)

Tracerlab, Richmond (AF)

TRW Systems

Westinghouse Electric Corporation, Lima

Westinghouse Electric Corporation, Lima (AF)

Westinghouse Electric Corporation (NASA)

Westinghouse Electric Corporation (WAL)

AEC Division of Technical Information Extension

AI Library (Includes 2 copies to CPAO, 2 copies to AEC, Washington,

2 copies to SFOO)
1

1

1

1

7

1

3

2

1

2

2

1

1

1

1

1

1

10 


\section{CONTENTS}

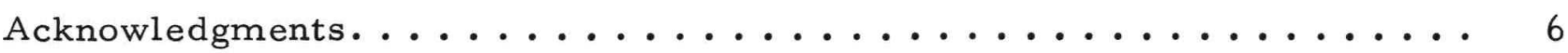

Abstract.............................. 7

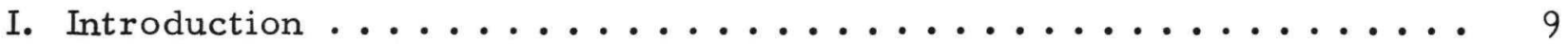

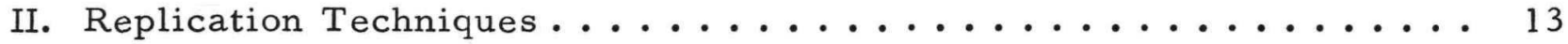

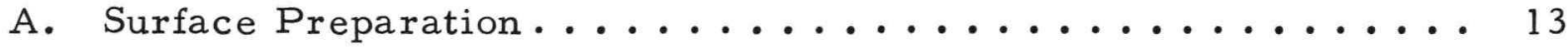

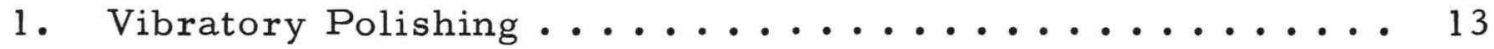

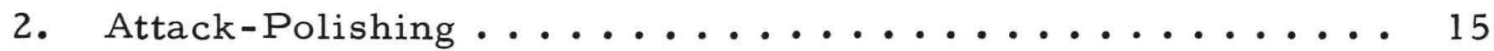

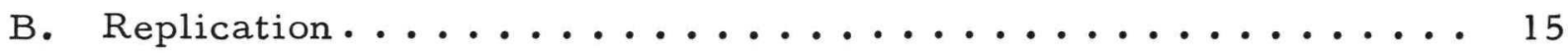

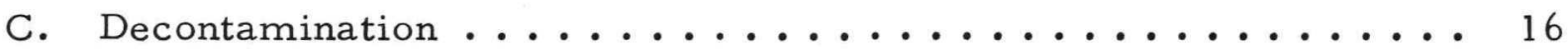

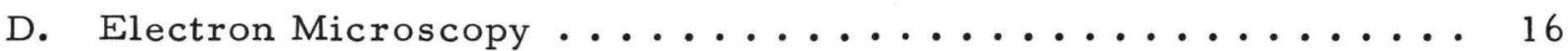

III. Electron Microscopy Analysis . . . . . . . . . . . . . . . 17

A. Unirradiated SNAP 8 Fuel .................. 17

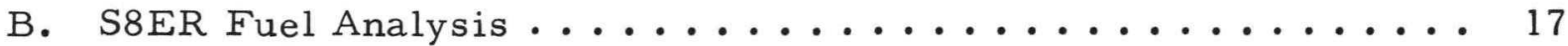

C. NAA 115-1 Fuel Analysis ................... 41

D. Fission Gas Bubble Analysis .................. 47

IV. Summary and Conclusions . . . . . . . . . . . . . . . 64

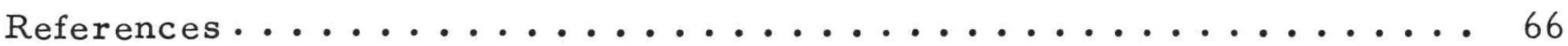

\section{TABLES}

1. Sample Selection for Electron Microscopic Analysis .......... 11

2. Electron Microscopy Observations of Irradiated SNAP 8 Fuel Samples 37

3. Fission Gas Bubble Measurements ................. 60

4. Volume Change Due to Fission Gas Bubble Formation . . . . . . . 6l

5. Bubble Depletion Zone Width Measurements About Uranium and Carbide Particle Sites . . . . . . . . . . . 62 


\section{FIGURES}

1. Equipment Used for Replication of SNAP Fuel In-Cell . . . . . . . 14

2. Typical Microcracks in Unirradiated U-ZrH Fuel After Being in a

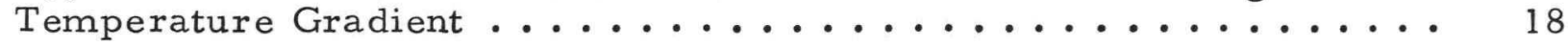

3. Cross Banding in Unirradiated U- $\mathrm{ZrH}$ Fuel After Being in a

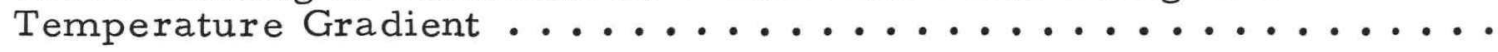

4. Fine and Coarse Banding in Unirradiated U-ZrH Fuel After Being in

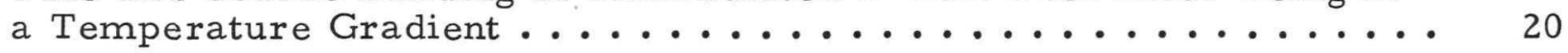

5. Large Carbide Particle in Unirradiated U-ZrH Fuel ......... 21

6. Possible Gamma Prime Particle in Unirradiated U-ZrH Fuel . . . . . 22

7. Cross Banding in Unirradiated U-ZrH Fuel .............. 23

8. Phase Boundary and Fission Gas Bubble Sites in the Element 432

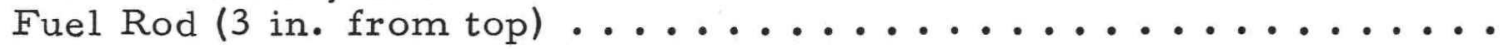

9. Bubble Depletion Region Around Large Particles in the Element 432

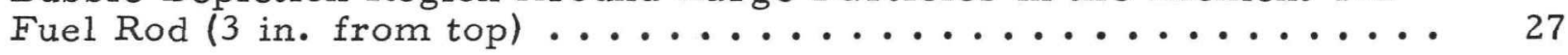

10. Microcrack in the Element 432 Fuel Rod (3 in. from top) . . . . . . 29

11. Surface Features in the Element 378 Fuel Rod (3 in. from top) ..... 31

12. Fission Gas Bubble Distribution in the Element 519 Fuel Rod $(6-1 / 2$ in. from top $) \ldots \ldots \ldots \ldots \ldots \ldots \ldots \ldots \ldots \ldots \ldots \ldots \ldots \ldots \ldots \ldots \ldots$

13. Fission Gas Bubble Depletion Regions Around Large Particle Sites in the Element 519 Fuel Rod (6-1/2 in. from top) ..........

14. Phase Boundary in the Element 232 Fuel Rod (5-3/4 in. from top) ...

15. Possible Phase Boundary in the Element 398 Fuel Rod

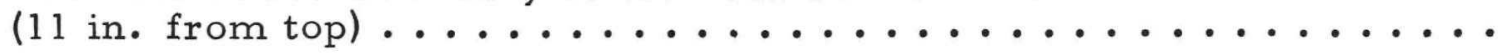

16. Surface Features in the Element 398 Fuel Rod (11 in. from top).....

17. Carbide Particles in the Element 111 Fuel Rod (11-1/2 in. from top) .

18. Surface Features in the Element 111 Fuel Rod (11-1/2 in. from top).. 43

19. Surface Features in the Element 188 Fuel Rod (5-1/2 in. from top)...

20. Possible Two-Phase Region in the Element 332 Fuel Rod

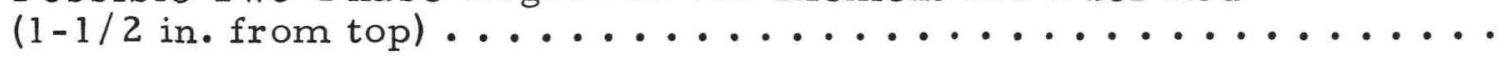

21. Surface Features of the Element 332 Fuel Rod (1-1/2 in. from top)...

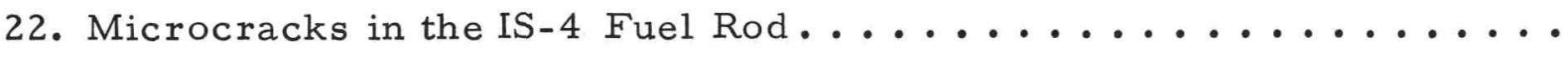
48

23. Fission Gas Bubbles in the IS-4 Fuel Rod............... 


\section{FIGURES}

24. Phase Boundary in the IS-4 Fuel Rod................ 51

25. Surface Features of the IS-7 Fuel Rod . . . . . . . . . . . . 53

26. Carbide Particle in the IS-8 Fuel Rod ............... 54

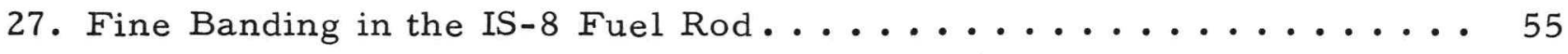

28. Fission Gas Bubbles in the IS-8 Fuel Rod. . . . . . . . . . 56

29. Phase Boundary and Gamma Prime Phase in the IS-8 Fuel Rod .... 57 


\section{ACKNOWLEDGMENTS}

The author is indebted to those personnel who helped to develop the replication techniques on irradiated fuel and in the subsequent electron microscope examination, photography, and analysis. I would particularly like to thank the following personnel:

W. V. Johnston

W. E. Krupp

D. D. McAfee

A. G. Pard

R. E. Forrester 
The irradiated fuel for this study was obtained from the SNAP 8 Experimental Reactor and the NAA 115-1 Capsule Irradiation Experiment. The fuel burnup achieved in these experiments was approximately 0.2 and 0.4 met. at. \%, respectively.

During the postirradiation examinations, physical measurements and metallography were performed on the fuel to determine volume changes and fuel microstructure. Metallog raphy revealed the fuel surface features up to $500 \mathrm{X}$ magnification; however, it was felt that further characterization of the fuel structure beyond that possible with optical metallography could be made through the use of an electron microscopic examination at selected fuel rod locations. Fuel samples were chosen both from regions of large volume change and excessive hydrogen loss.

Examination of the replica photographs revealed alpha uranium sites, carbide particle sites, phase boundaries, epsilon banding, and fission gas bubbles. Fuel microcracking was observed in some samples but was not excessive. Bubble density measurements on the order of $10^{13}$ bubbles/cc were typical, with an average bubble diameter of $900 \AA$.

Fission gas bubble formation accounted for approximately $50 \%$ of the observed hydrogen-corrected volume change in the peak distortion region from samples analyzed from two S8ER fuel rods. Analysis of the S8ER data indicated a possible dependence of fission gas bubble size and density on temperature. However, there did not appear to be a correlation with fuel burnup.

Based on the fuel samples examined, there was no evidence of fission gas bubble sweeping during phase change. No correlation was found between the location of fission gas bubble sites and epsilon banding or microcracks.

Bubble depletion regions observed around large particle sites are thought to be a result of the interaction of the gas bubbles with the larger uranium and carbide particles.

$$
\text { NAA - SR - } 12449
$$




\section{BLANK}




\section{INTRODUCTION}

The irradiated fuel for this study was obtained from the SNAP 8 Experi mental Reactor (S8ER) and the NAA 115-1 Capsule Irradiation Experiment.

The S8ER, first in a series of SNAP 8 nuclear tests, was operated to determine reactor performance characteristics and to demonstrate sustained operation at design power. SNAP 8 is a NaK-cooled, highly enriched uraniumzirconium hydride fueled, compact nuclear power system designed to operate at $600 \mathrm{kwt}$ with a $1300^{\circ} \mathrm{F}$ reactor coolant outlet temperature. Nuclear testing of the reactor was conducted over the period from November 22, 1963 to April 15, 1965. The reactor experienced a total of 12,000 hr of operation with $5 \times 10^{6} \mathrm{kwh}$ energy release, of which 8,760 hr ( 1 year) were between 400 and $600 \mathrm{kwt}$ with coolant temperatures at $1300^{\circ} \mathrm{F}$. The peak burnup achieved by the fuel was approximately 0.25 met. at. $\%$.

The S8ER reactor core was shipped as a unit to the AI Hot Laboratory in the summer of 1965 for a postirradiation examination. Detailed analysis of the fuel from selected elements revealed localized swelling which was primarily the result of hydride fuel phase transformation.

The NAA 115-1 irradiation experiment consisted of twelve sub-length fuel elements which were irradiated simultaneously in a single facility of the Hanford K - East Reactor to design conditions of 0.4 met. at. \% burnup in 10,000 hr. The fuel elements contained U-Zr hydride, and were typical of the S8ER design except for their lengths, internal clearances, and the range of their fuel compositions. Design fuel compositions included 1.60, 1.70, and $1.85 \mathrm{H} / \mathrm{Zr}$ ratios, and $0.02,0.1$, and 0.4 wt $\%$ carbon grain refiner additions. The elements were contained in six separate experimental units, which provided a means of controlling the maximum fuel temperatures at different levels ranging from 1300 to $1600^{\circ} \mathrm{F}$. This was done to establish the effect of temperature and major compositional variables on the dimensional stability of the fuel.

Following discharge from the reactor, the experiment was shipped to the AI Hot Laboratory (AIHL) for a postirradiation examination, where 11 of the 12 fuel elements were revealed to be in excellent condition. For the temperatures, grain refiner additions, and hydrogen concentrations covered, fuel swelling was in the range of 2 to $4 \mathrm{vol} \%$. (2)

NAA -SR - 12449 
During both the S8ER and NAA $115-1$ postirradiation examinations, fuel metallography samples were obtained from the fuel rods at selected locations which were representative of the various observed fuel swelling characteristics. Metallographic examination of the fuel revealed the microstructure and surface features, such as cracks and $\mathrm{NaK}$ reaction effects, at magnifications up to 500X. Further characterization of the fuel structure was made through the use of an electron microscopic examination at selected fuel rod locations.

Irradiation of fuel materials typically produces swelling, with a major cause being the formation of fission gas bubbles. The distribution of these bubbles in the lattice of the fuel material can have profound effects on the swelling behavior of the fuel. Precipitates, grain and phase boundaries, cracks and imperfections affect the distribution of fission gas bubbles and the macroscopic behavior of the fuel. By performing an electron microscopic examination of irradiated SNAP 8 fuel, it was possible to detect the microstructural details not observed by optical microscopy and, in particular, to determine fission gas bubble density.

A total of nine S8ER fuel samples, three NAA 115-1 fuel samples, and three unirradiated samples had their surfaces replicated for electron microscope examination. The samples were chosen from the following areas of fuel behavior:

1) Regions of suspected delta-to-delta plus beta transformation as evidenced by large volume changes and low final hydrogen contents.

2) Regions of suspected delta-to-epsilon transformation as evidenced by small volume changes and hydrogen contents equal to or greater than the preirradiation values.

3) Unusual phenomena, such as very large volume changes and unexpected postirradiation hydrogen contents.

Each sample, and its reason for selection, is listed in Table 1.

Prior to this time, replication at AIHL had not been demonstrated as routine. Therefore, technique development performed remotely on irradiated samples was necessary before successful replicas could be obtained. The procedures developed at the Hot Lab are discussed briefly in the following section of this report.

$$
\text { NAA-SR - } 12449
$$


TABLE 1

SAMPLE SELECTION FOR ELECTRON MICROSCOPIC ANALYSIS

\begin{tabular}{c|c|c|c|c}
\hline \hline Experiment & $\begin{array}{c}\text { Element } \\
\text { No. }\end{array}$ & $\begin{array}{c}\text { Core } \\
\text { Location }\end{array}$ & $\begin{array}{c}\text { Axial Iocation on Rod } \\
\text { (Distance from top, in. })\end{array}$ & $\begin{array}{c}\text { Reason for Selection } \\
\text { As Listed in Text }\end{array}$ \\
\hline S8ER & 432 & VIII-29 & 3 & 1 \\
S8ER & 332 & VIII-25 & $1-1 / 2$ & 3 \\
S8ER & 188 & VIII-6 & $5-1 / 2$ & 3 \\
S8ER & 378 & IX-28 & 3 & 2 \\
S8ER & 378 & IX -28 & $11-1 / 2$ & 2 \\
S8ER & 111 & IX -42 & $11-1 / 2$ & 2 \\
S8ER & 232 & VI-24 & $5-3 / 4$ & 2 \\
S8ER & 519 & IV-1 & $6-1 / 2$ & 2 \\
S8ER & 398 & IV-13 & 11 & 2 \\
$115-1$ & IS-4 & - & 2 & 2 \\
$115-1$ & IS-7 & - & 2 & 3 \\
$115-1$ & IS-8 & - & 2 & 2 \\
\hline
\end{tabular}

NAA - SR - 12449 


\section{BLANK}




\section{REPLICATION TECHNIQUES}

Radioactive materials emitting high levels of beta and gamma activity present a major handling problem and cannot be directly examined in the electron microscope. Examination of thin foils of a radioactive material is possible only if the radioactivity rapidly decays to a low level. However, replication provides a means of transferring the surface characteristics of a highly radioactive sample to a low-level sample that can be examined in a nonshielded area.

Plastic, carbon, and oxide replicas are commonly used to prepare surfaces for examination with the electron microscope. ${ }^{(3)}$ Plastic replicas were selected due to apparent advantages in ease of remote operations. Use of plastic replication techniques involves careful metallographic processing and cleaning of the specimen surface. The replica, which is a negative of the specimen surface, can be stripped from the sample with a suitable backing material. The contrast on such replicas can be improved by shadowing the plastic with heavy metals (gold, platinum, chromium) or carbon, ${ }^{(4)}$ producing ultimate resolution of $200 \AA$.

Replication techniques were first attempted with unirradiated fuel material out-of-cell to conserve expensive in-cell development time. Techniques successful with unirradiated fuel were then tested in-cell with irradiated fuel.

\section{A. SURFACE PREPAR ATION}

It was not possible to successfully replicate as-etched fuel due to the pitting and extreme relief produced during electrolytic etching. However, the presence of hard zirconium carbide inclusions in SNAP fuel caused relief effects in aspolished samples that led to tearing of replicas. Consequently, attach-polishing and vibratory polishing techniques were evaluated.

\section{Vibratory Polishing}

Specimens were ground on 240-, 320-, and 600-grit SiC papers using copious amounts of water as the lubricant to prevent accumulation of material previously removed. Papers were changed after five minutes use, and the specimens were ultrasonically cleaned in water following each grinding step to remove all traces of abrasive. 


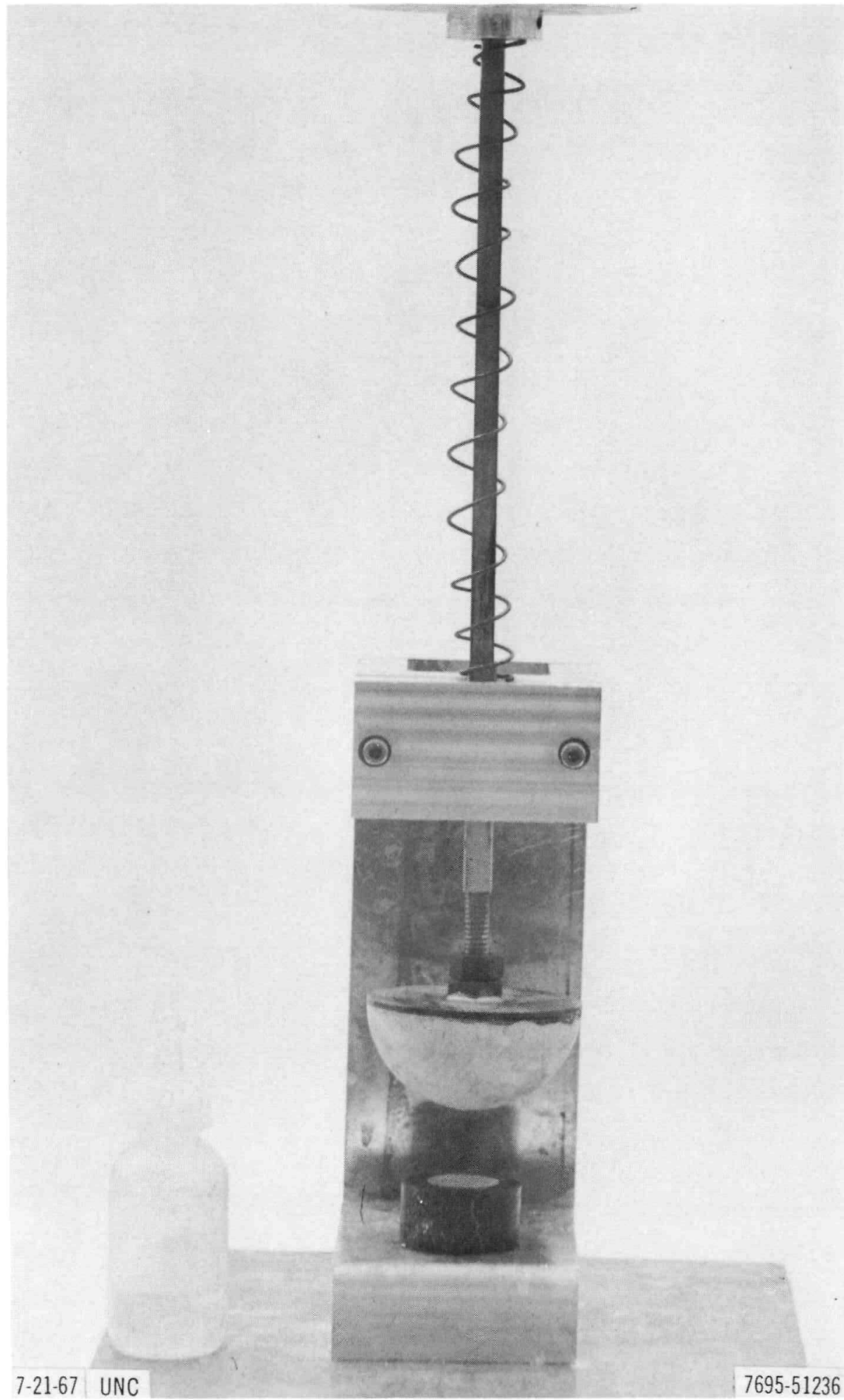

Figure 1. Equipment Used for Replication of SNAP Fuel In-Cell

NAA -SR - 12449

14

CONIDENTIA $L^{\circ}$ 
Rough polishing was accomplished using a rayon cloth and water slurries of 6- and 2-micron diamond paste for 15 minutes each. The final polishing took two hours on a Buehler Vibromet, using a slurry of Linde-B in a $10 \%$ oxalic acid solution on rayon cloth.

Replication of surfaces of unirradiated materials prepared by vibratory polishing out-of-cell showed resolution down to 200 to $300 \AA$. Replication of surfaces of irradiated materials prepared by vibratory polishing in-cell commonly showed scratches and disturbed metal. This was attributed to variation in abrasive cake depth (Linde-B), accenturated by the high in-cell air flow, which caused accelerated evaporation of the carrier. Attempts to replicate surfaces prepared by vibratory polishing in-cell were terminated.

\section{Attack-Polishing}

Grinding operations were identical to those described in the preceding section. Specimens were polished on rayon cloth, using alternate applications of polishing media. A Linde- $\mathrm{B} / \mathrm{H}_{2} \mathrm{O}$ slurry was applied to the polishing wheel and allowed to remain for five minutes. This was followed by the addition of a mixture containing $200 \mathrm{ml} \mathrm{H}_{2} \mathrm{O}, 25 \mathrm{ml}$ concentrated $\mathrm{HNO}_{3}$, and 4 to 6 drops of $48 \% \mathrm{HF}$. After 30 seconds, a $10 \%$ oxalic acid solution was added in sufficient quantity to completely wash away the acid mixture. These operations continued for 1-1/2 hours, when the grain structure was faintly discernible, indicative of a faint chemical etch. (5) Replications of surfaces prepared by attack-polishing with unirradiated and irradiated fuel were equally successful.

\section{B. REPLICATION}

The replicating solution was prepared by dissolving one gram of Faxfilm (cellulose acetate) in $50 \mathrm{ml}$ of acetone. A squeeze bottle held by a masterslave manipulator was used to apply four drops of this solution to the specimen surface. A small strip of Faxfilm, $3.0 \mathrm{in.}$ long by $1.0 \mathrm{in}$. wide by $0.005 \mathrm{in}$. thick, was immediately pressed onto the specimen surface. Approximately ten pounds of pressure was applied for 30 seconds by means of a spherical rubber tip (see Figure 1). After a three-minute wait to allow curing, the replica so obtained represented a negative of the entire specimen surface. This operation was repeated three to six times, depending on the surface condition of the specimen, to remove large particles of loose fuel and contaminants. The final replica was ultrasonically cleaned in water and removed from the cell.

$$
\text { NAA-SR - } 12449
$$




\section{DECONT AMINATION}

The cellulose acetate plastic used cannot be cleaned in concentrated acids such as $\mathrm{HNO}_{3}$ or $\mathrm{HF}$ without being destroyed. Cleaning was accomplished by placing the replica in a $10 \% \mathrm{NH}_{4} \mathrm{OH}$ solution and shaking approximately 100 times. This was followed by three similar rinses in distilled $\mathrm{H}_{2} \mathrm{O}$. These operations removed much of the particulate contamination, lowering the activity of the replica to below $5 \mathrm{~m}-\mathrm{rad} / \mathrm{hr}$ (beta plus gamma). The replica was taped to a glass slide, holding up the face that contacted the specimen.

\section{ELECTRON MICR OSCOPY}

The Faxfilm replicas were shadowed in a vacuum evaporator with $\mathrm{B}_{2} \mathrm{O}_{3}$ at an angle of $90 \mathrm{deg}$, chromium at $30 \mathrm{deg}$, and carbon at $90 \mathrm{deg}$. The entire assembly was placed in water to dissolve the $\mathrm{B}_{2} \mathrm{O}_{3}$ and plastic from the chromium-carbon secondary replica, which was then picked up with grids and inserted into the electron microscope for examination. 


\section{ELECTRON M̀ICROSCOPY ANALYSIS}

\section{A. UNIRR ADIATED SNAP 8 FUEL}

The unirradiated fuel examined consisted of three test samples heated to $1400^{\circ} \mathrm{F}$ with a temperature gradient that probably caused the $\mathrm{H} / \mathrm{Zr}$ ratio to vary from 0.9 to 1.5. Optical metallography of the fuel revealed epsilon banding and microcracking. Differences between alpha uranium sites and carbide particles cannot be definitely determined from the electron microscope photographs; however, as a rule, the uranium sites are circular in shape while the carbide particles are more angular in nature.

Figure 2 is a typical example of the fuel surface showing microcracks, alpha uranium sites, coarse and fine twinning which are probably epsilon ghosts, and surface debris or artifacts. Figures 3, 4, and 5 show typical surface features on the second fuel sample. Figure 3 shows typical uranium and/or carbide sites along with banding. Whether the banding observed in this or subsequent photographs is real or ghosts can only be ascertained from the actual hydrogen content. Figure 4 indicates wide and fine banding. A phase boundary can be seen along one corner of the photograph. A large carbide particle can be seen in Figure 5. Gamma prime particles on a replica tend to be long and thin, as shown in Figure 6. Banding at right angles along with fine sub-banding is shown in Figure 7. This phenomenon could easily occur in fuel which had been repeatedly thermal cycled resulting in hydriding and dehydriding of the fuel. The features observed in these replicas of unirradiated fuel were used for comparison with the irradiated fuel replicas.

\section{B. S8ER FUEL ANALYSIS}

The first replicas to be discussed will be those taken from fuel regions of large volume changes (greater than $4 \%$ swelling based on hydrogen corrected data). These were regions of suspected delta-to-delta plus beta phase transformation during reactor operation. The postirradiation hydrogen content of these fuel samples ranged from 1.54 to $1.61 \mathrm{H} / \mathrm{Zr}$. All of the samples contained a high carbon content ranging from 0.34 to 0.54 wt $\%$.

The replicated fuel samples came from elements 432, 378, 232, 519, and 398. The location of the fuel sample from element 398 was a substitute sample,

$$
\text { NAA-SR - } 12449
$$




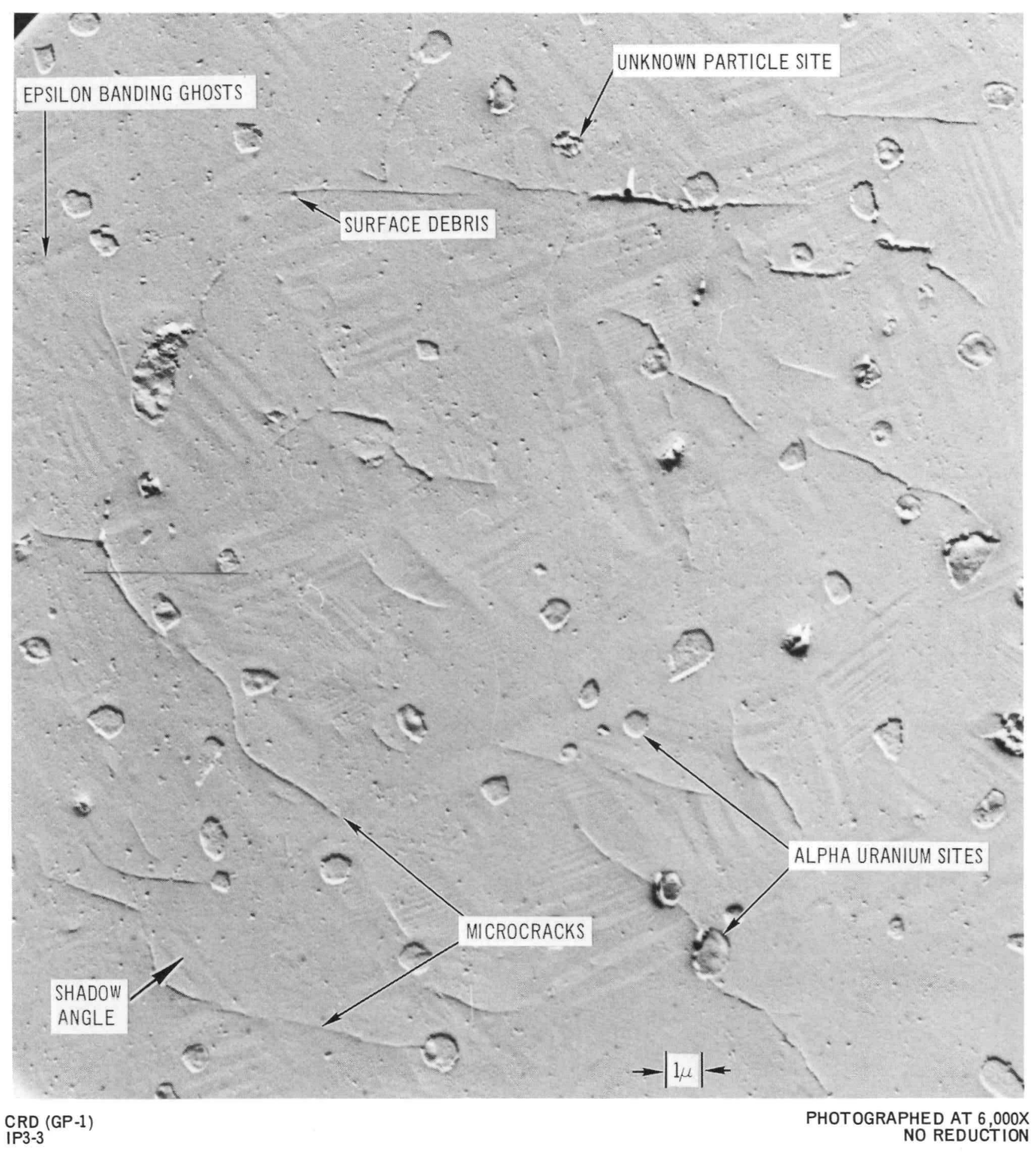

Figure 2. Typical Microcracks in Unirradiated U-ZrH Fuel After Being in a Temperature Gradient

NAA -SR - 12449

18 

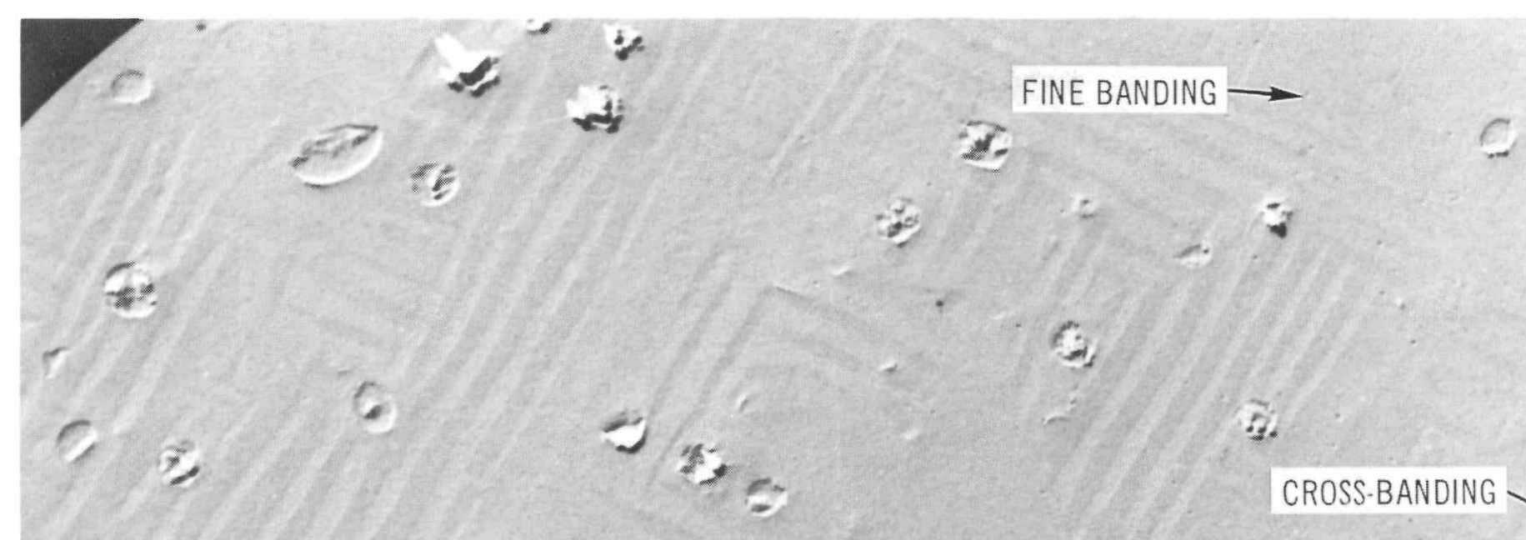

3.

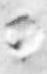

$x^{5}$

as

\$5;
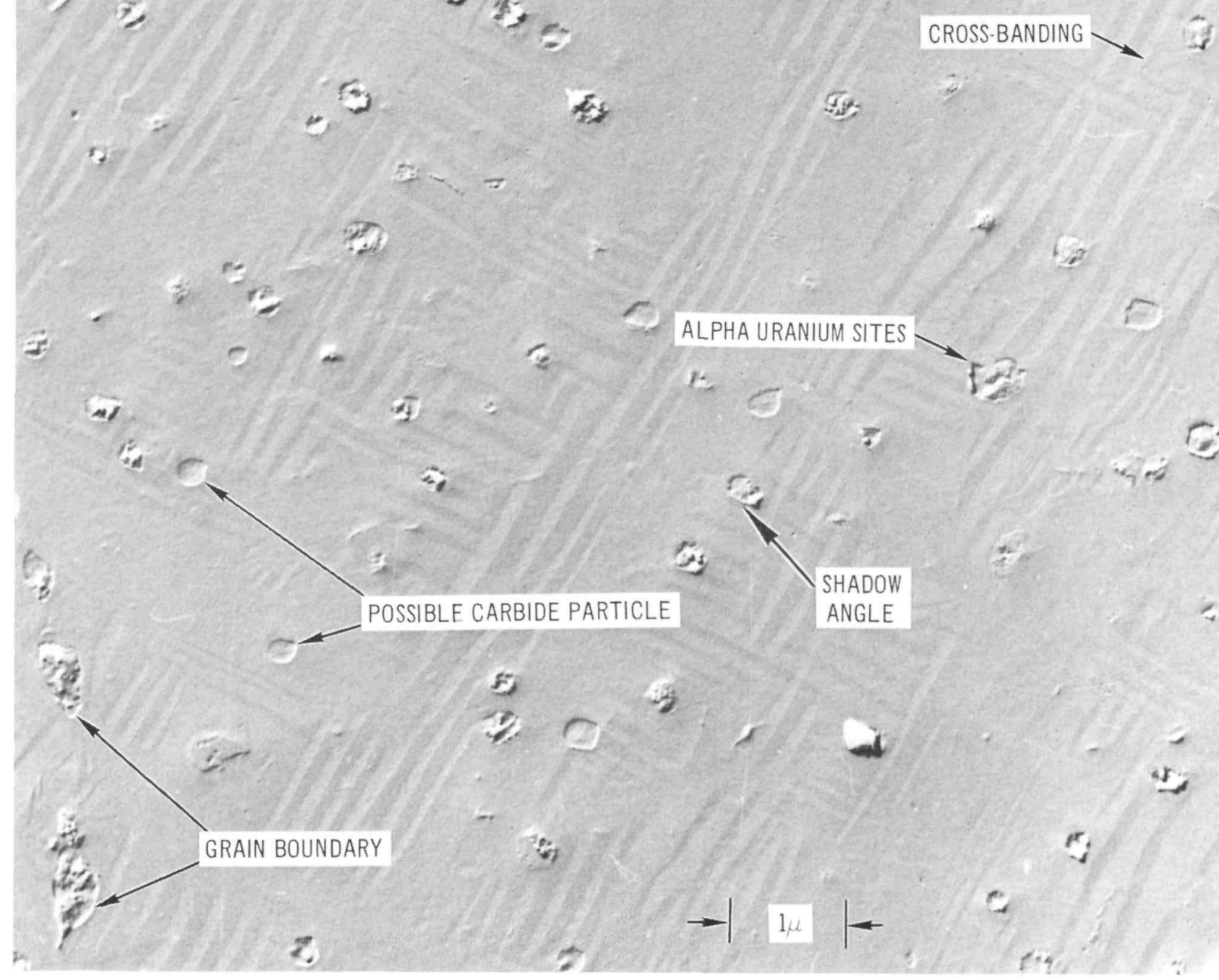

F
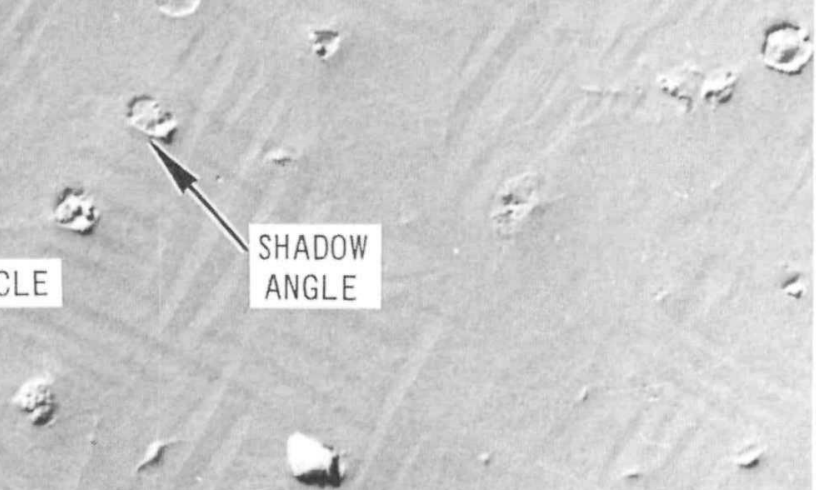

$-$

$\underset{I P 4-5}{C R D}(\mathrm{GP}-1)$

PHOTOGRAPHED AT $15,000 \mathrm{X}$

Figure 3. Cross Banding in Unirradiated U-ZrH Fuel After Being in a Temperature Gradient 


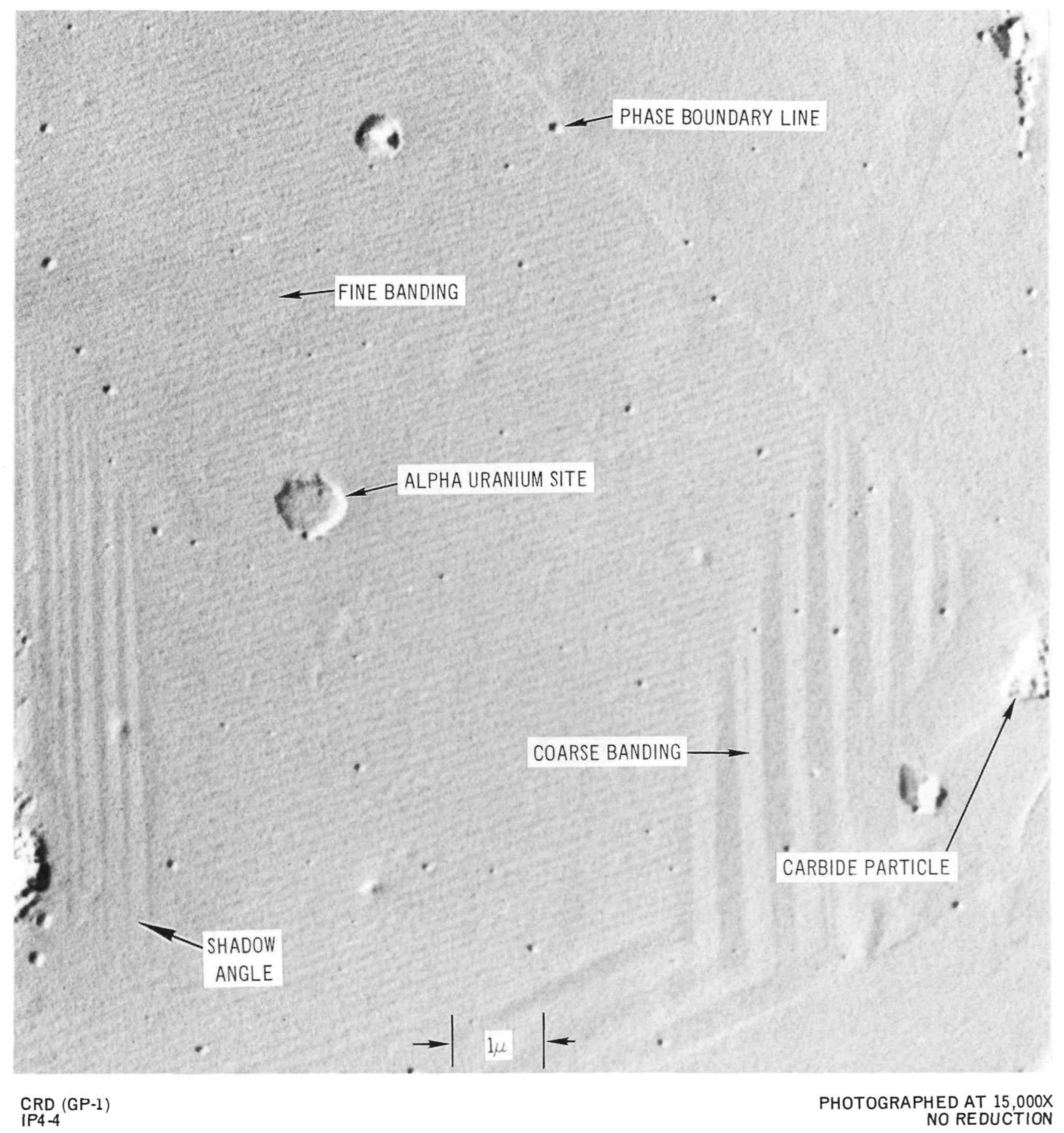

Figure 4. Fine and Coarse Banding in Unirradiated U-ZrH Fuel After Being in a Temperature Gradient

NAA -SR - 12449

20 


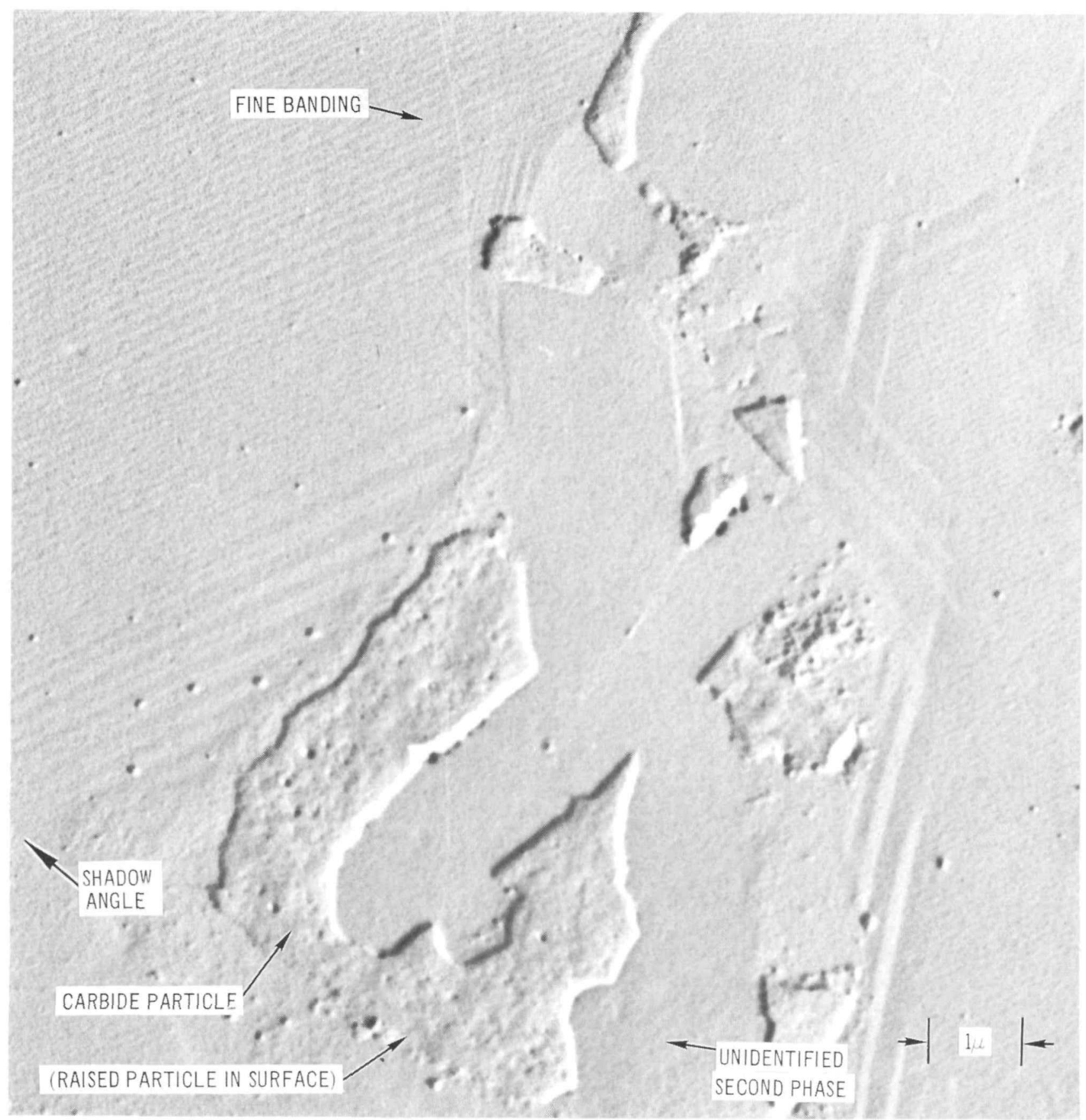

CRD (GP-1)

PHOTOGRAPHED AT $15,000 \mathrm{X}$
NO REDUCTION

Figure 5. Large Carbide Particle in Unirradiated U- $\mathrm{ZrH}$ Fuel

NAA - SR - 12449

21 

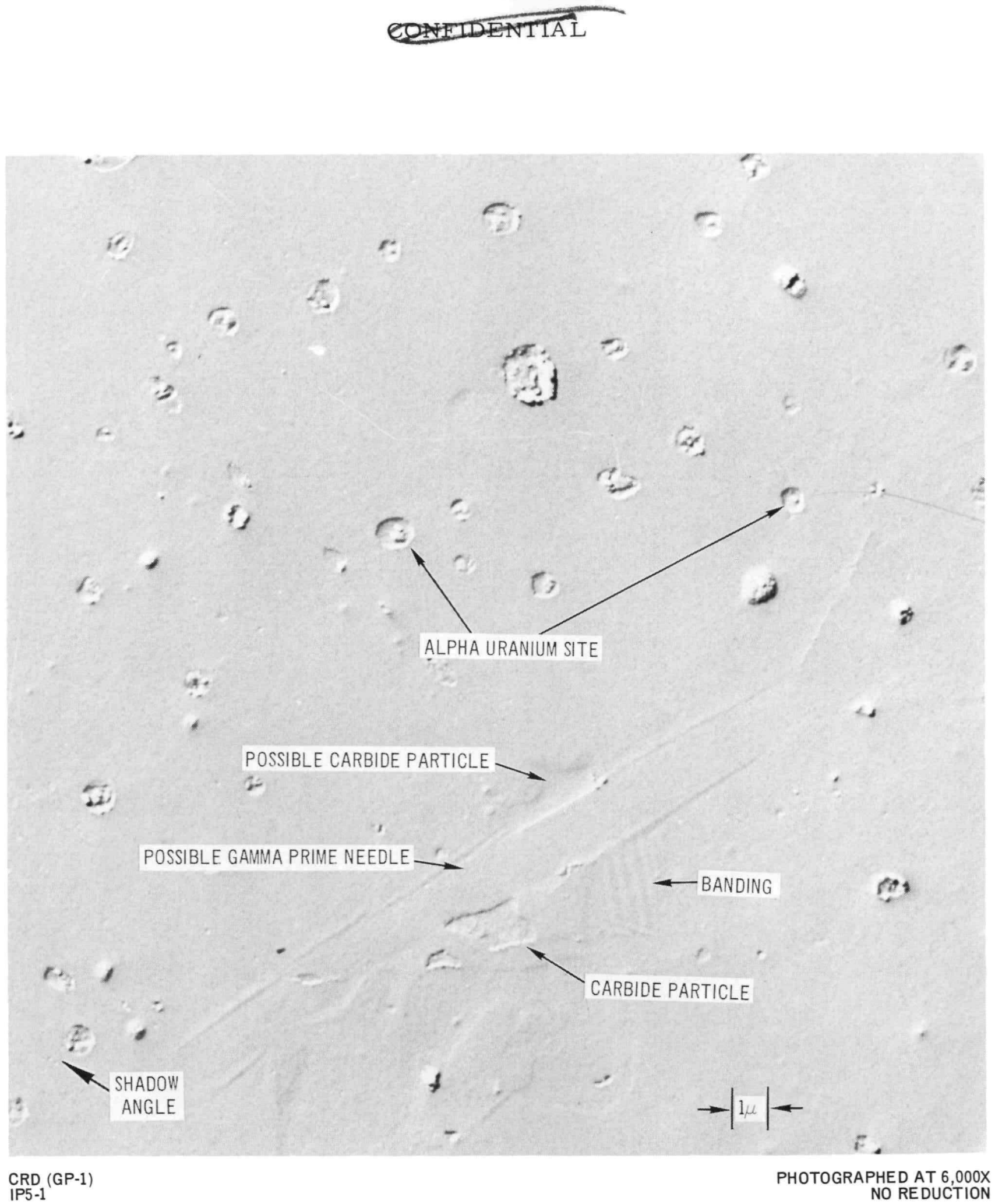

Figure 6. Possible Gamma Prime Particle in Unirradiated U-ZrH Fuel

NAA -SR - 12449

22 


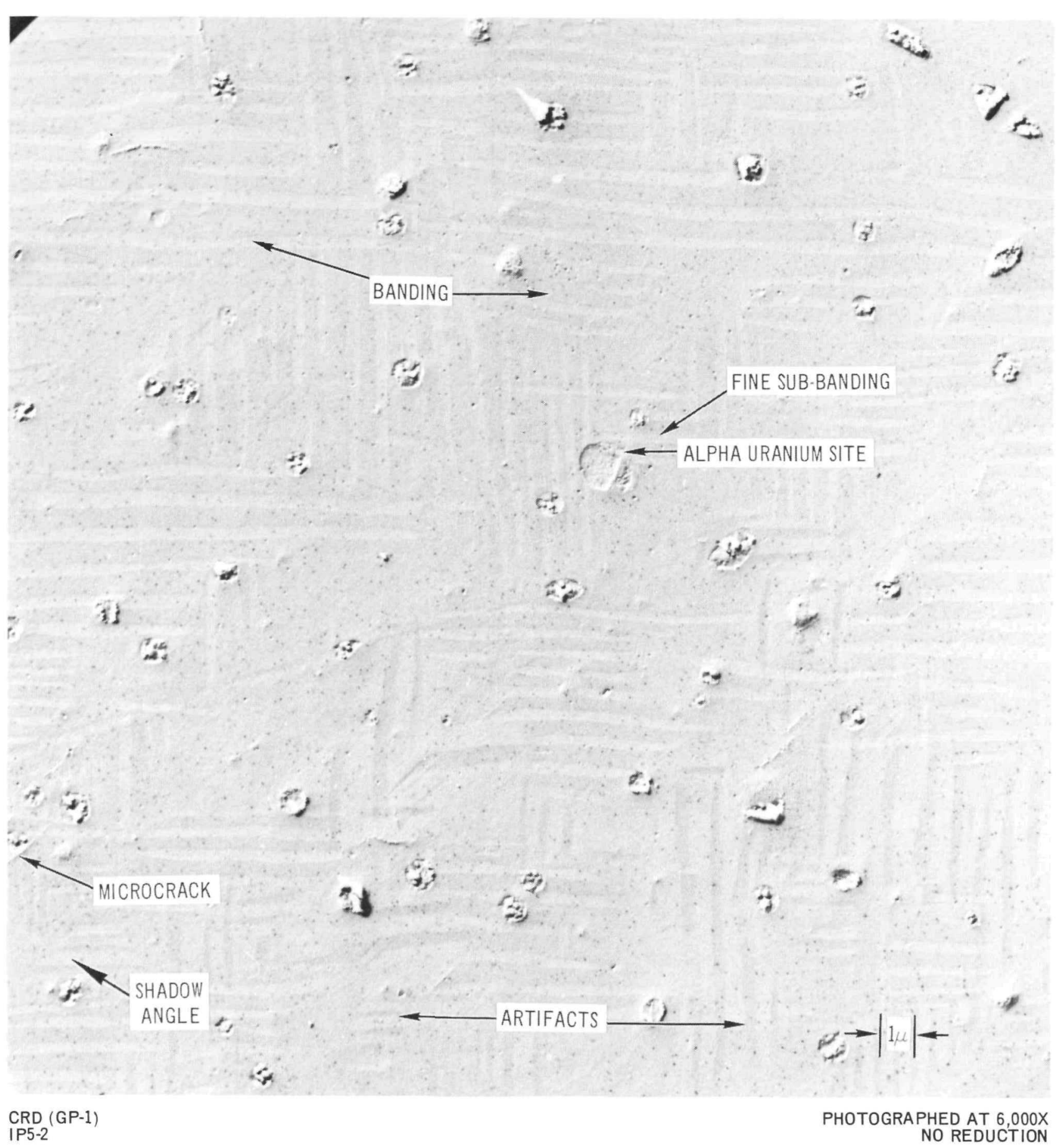

Figure 7. Cross Banding in Unirradiated $\mathrm{U}-\mathrm{ZrH}$ Fuel

NA A - SR - 12449

23 
unfortunately not in the desired location, and had to be taken from the lower portion of the fuel rod. The other four samples were obtained from the upper portion of the fuel rods in the region of maximum fuel temperature during reactor operation.

In all of the photographs, alpha uranium sites, epsilon banding and subbanding, carbide particles, and phase boundaries were a common occurrence. Fission gas bubbles were observed in the fuel from elements 519, 432, and possibly 232. However, with insufficient magnification of the photographs on the replicas from element 232, it was not possible to positively resolve whether these particles were fission gas bubbles or surface debris, which was quite common on all replicas. It was of interest to note that the re were bubble depletion regions around the large particles, particularly carbide and uranium sites. Also, grain or phase boundaries were noticeably void of fission gas bubbles. Figures 8, 9, and 10 show the surface features of the fuel from element 432. Figures 11 through 16 show typical surface features on the fuel from elements 378, 519, 232, and 398. Figures 14 and 15 show carbide and uranium particles lined up along a phase boundary. No evidence of fission gas bubbles was observed in the fuel structure of element 378, which had a large volume change. However, replication of the fuel from this element was poor, and no high magnification photographs were obtained which may have revealed the presence of bubbles.

Fission gas bubble density measurements were made at selected locations to determine the number of bubbles per cc. Also, distances were measured between the particles and the fission gas bubbles to determine the width of the bubble void areas around the particle sites. These results are discussed later in this report. A summary of the electron microscopy observations is presented in Table 2: Listed with these observations are the fuel rod diameter, percent diameter change, uncorrected and hydrogen corrected volume changes, carbon content, fuel burnup, hydrogen content, and optical metallography observations at the locations each of the replicas were taken.

Replicas were taken from two fuel surfaces which exhibited a large postirradiation hydrogen content equal to or greater than the preirradiation values. Two elements which exhibited this characteristic were 111 and 378, $11-1 / 2$ in. from the top of the element. These regions were suspected of crossing the 


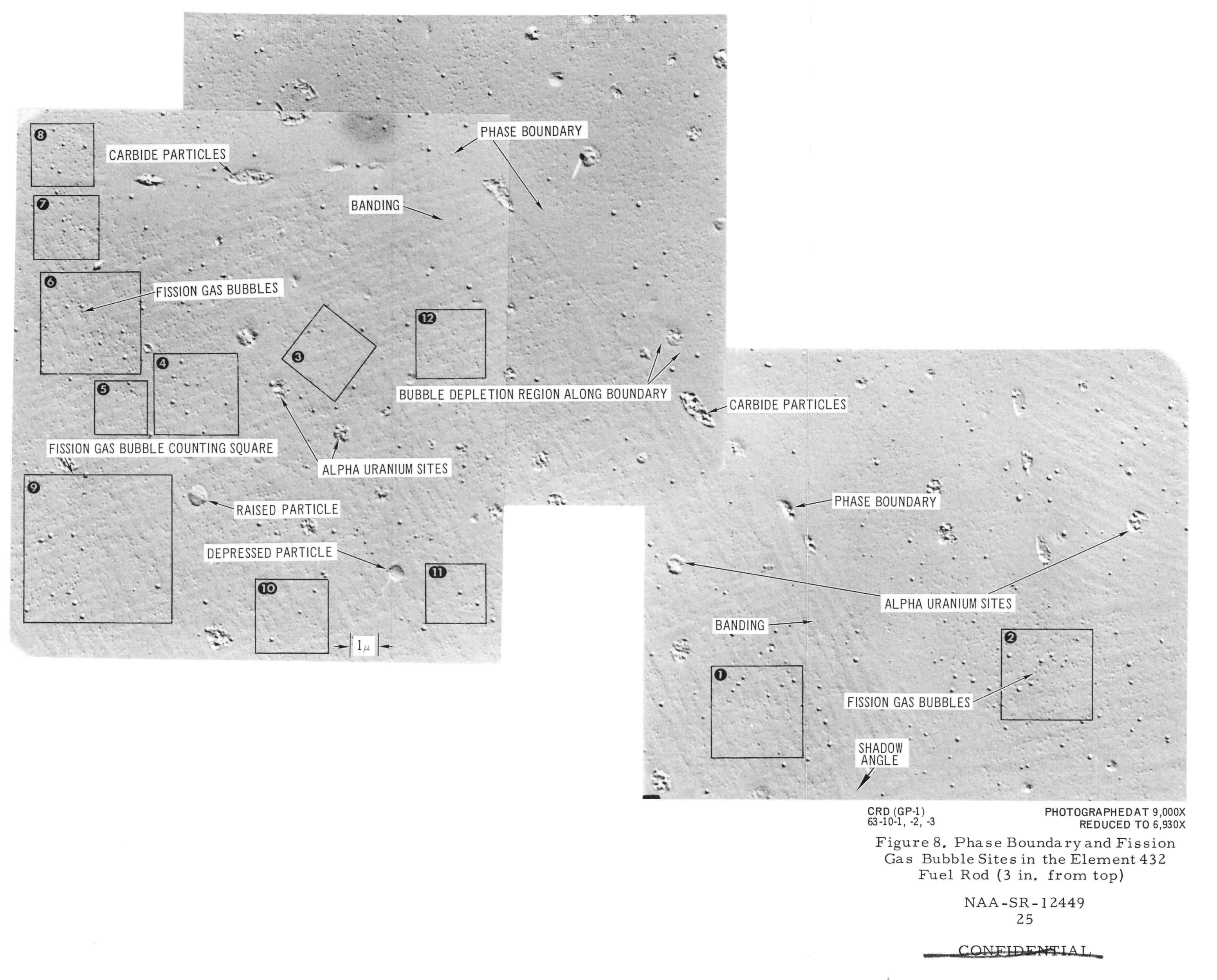




\section{BLANK}




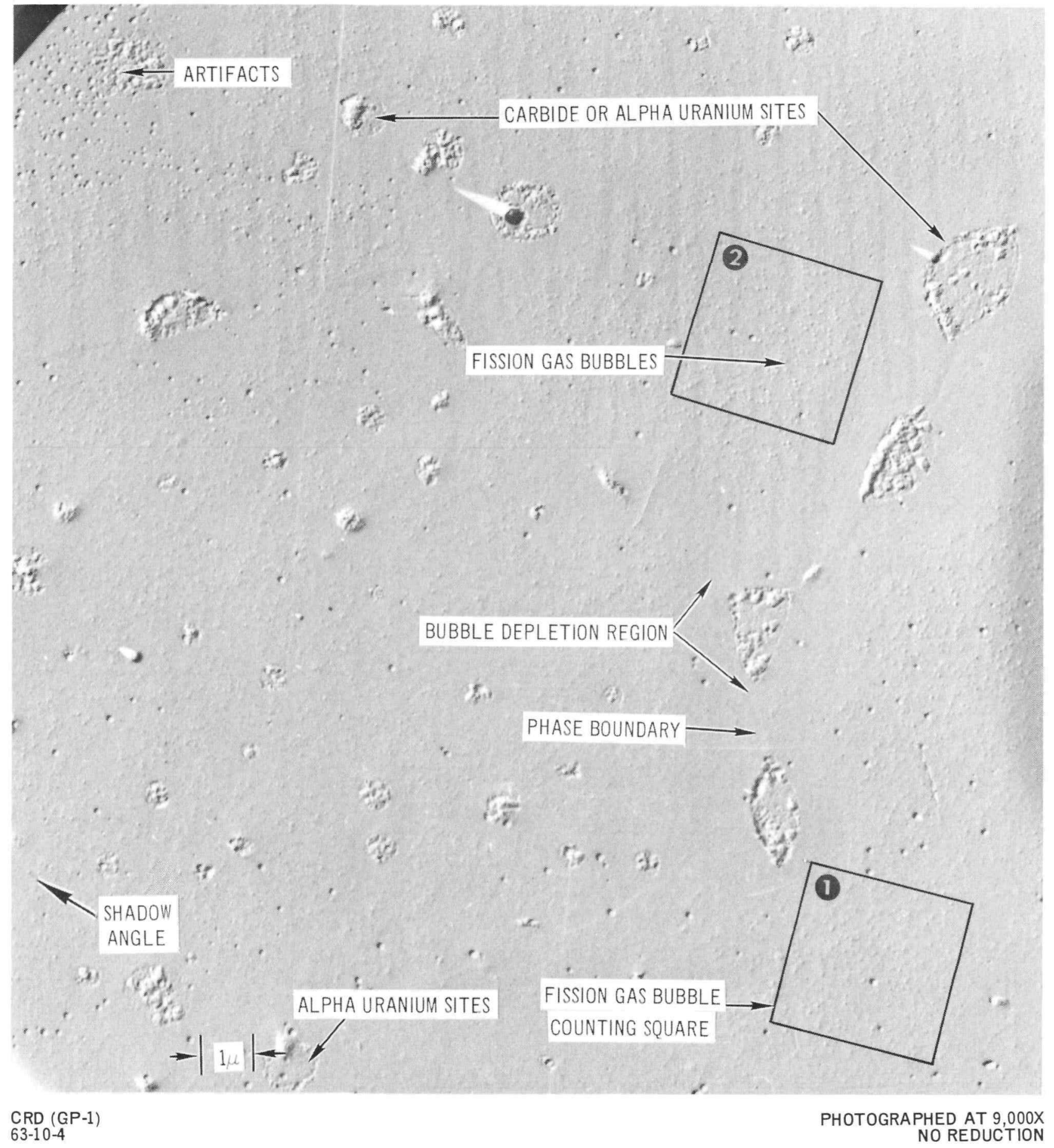

Figure 9. Bubble Depletion Region Around Large Particles in the Element 432 Fuel Rod

( 3 in. from top)

NAA -SR - 12449 


\section{BLANK}




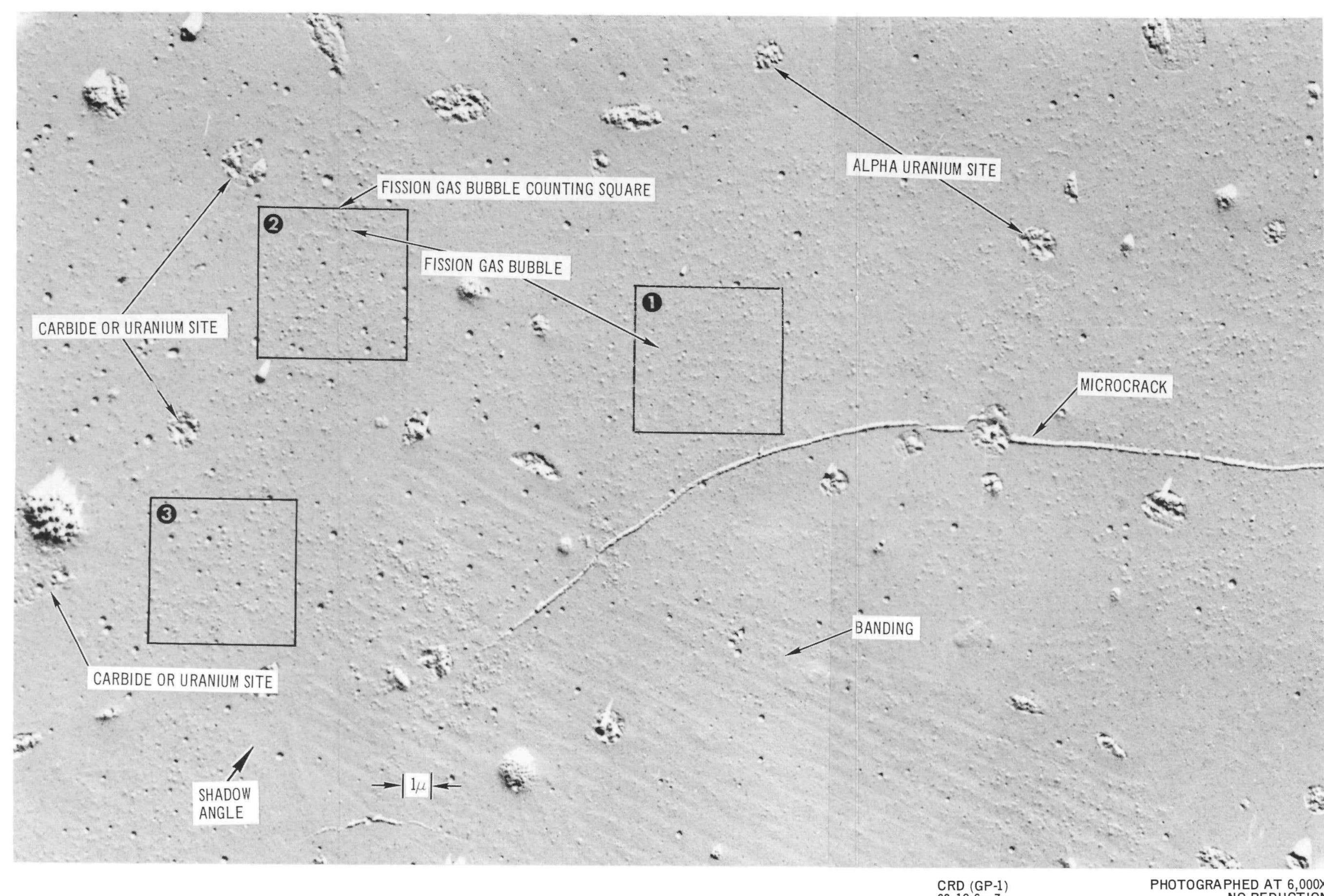

$\underset{\substack{\text { CRD }(G P-1) \\ 63-106,-7}}{-10}$

PHOTOGRAPHED AT G,000X
NO REDUCTIOX

Figure 10. Microcrack in the Elemen

432 Fuel Rod
(3 in. from top) 


\section{BLANK}



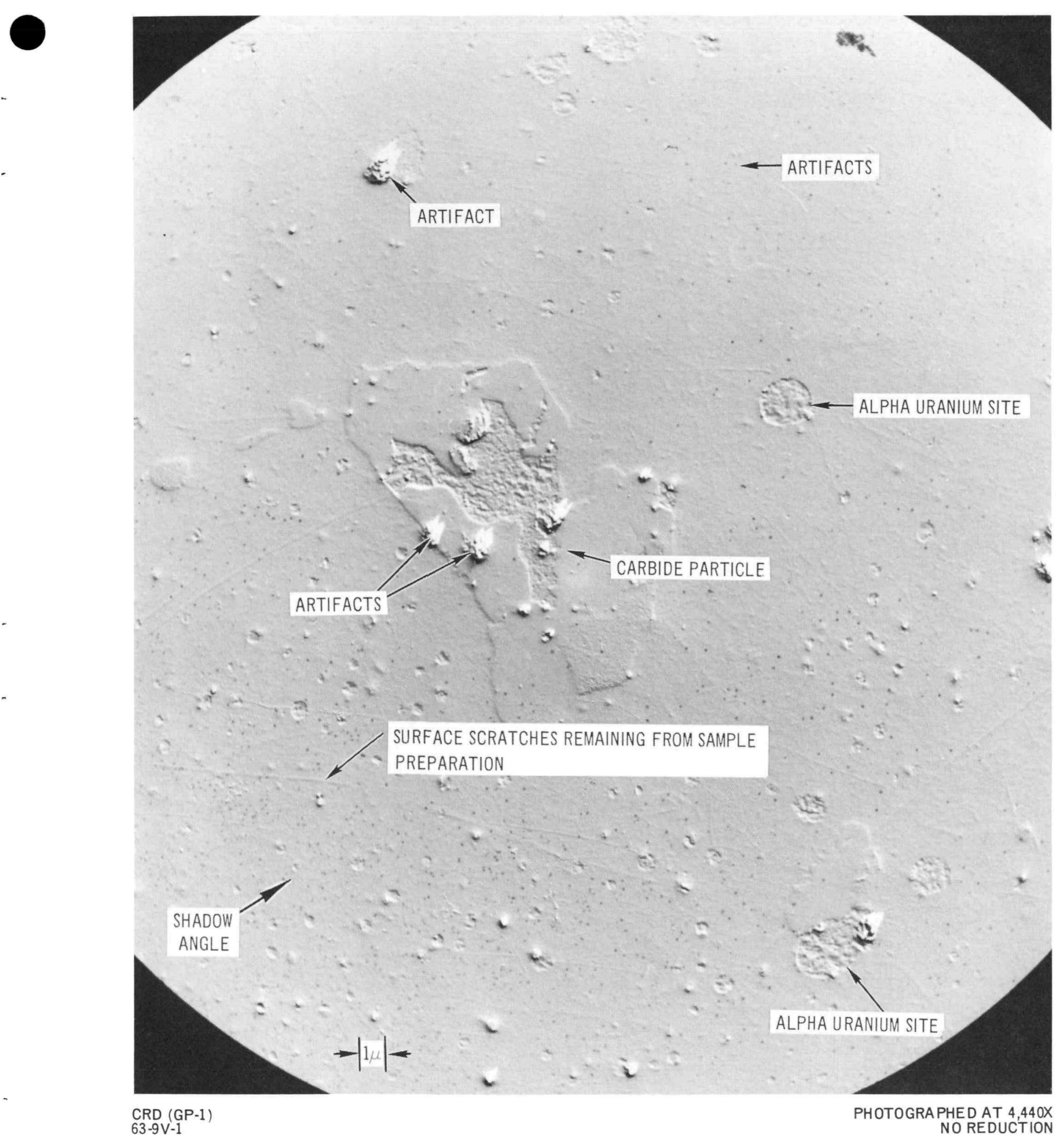

Figure 11. Surface Features in the Element 378 Fuel Rod ( 3 in. from top)

NAA -SR - 12449 


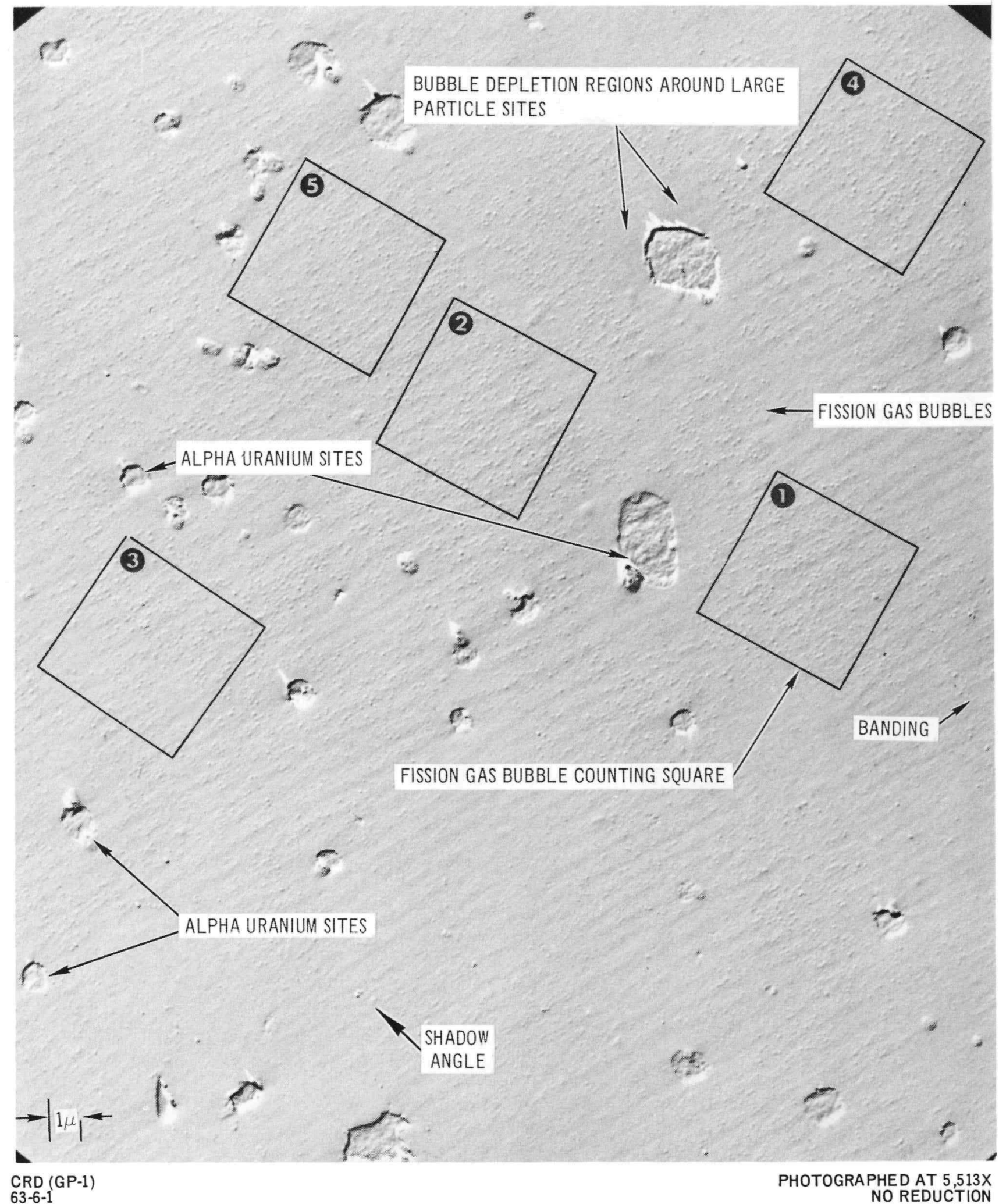

Figure 12. Fission Gas Bubble Distribution in the Element 519 Fuel Rod (6-1/2 in. from top)

$$
\text { NAA -SR - } 12449
$$



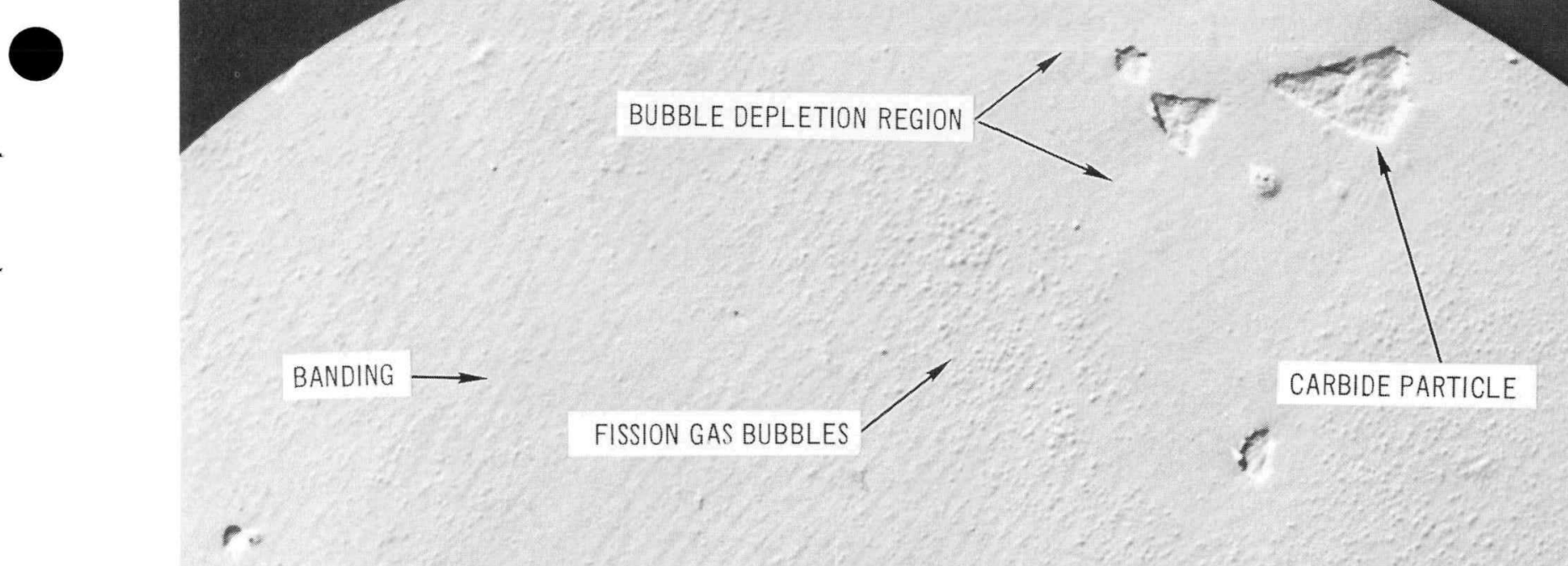

BANDING $\longrightarrow$

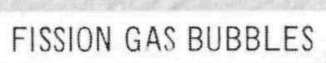

.
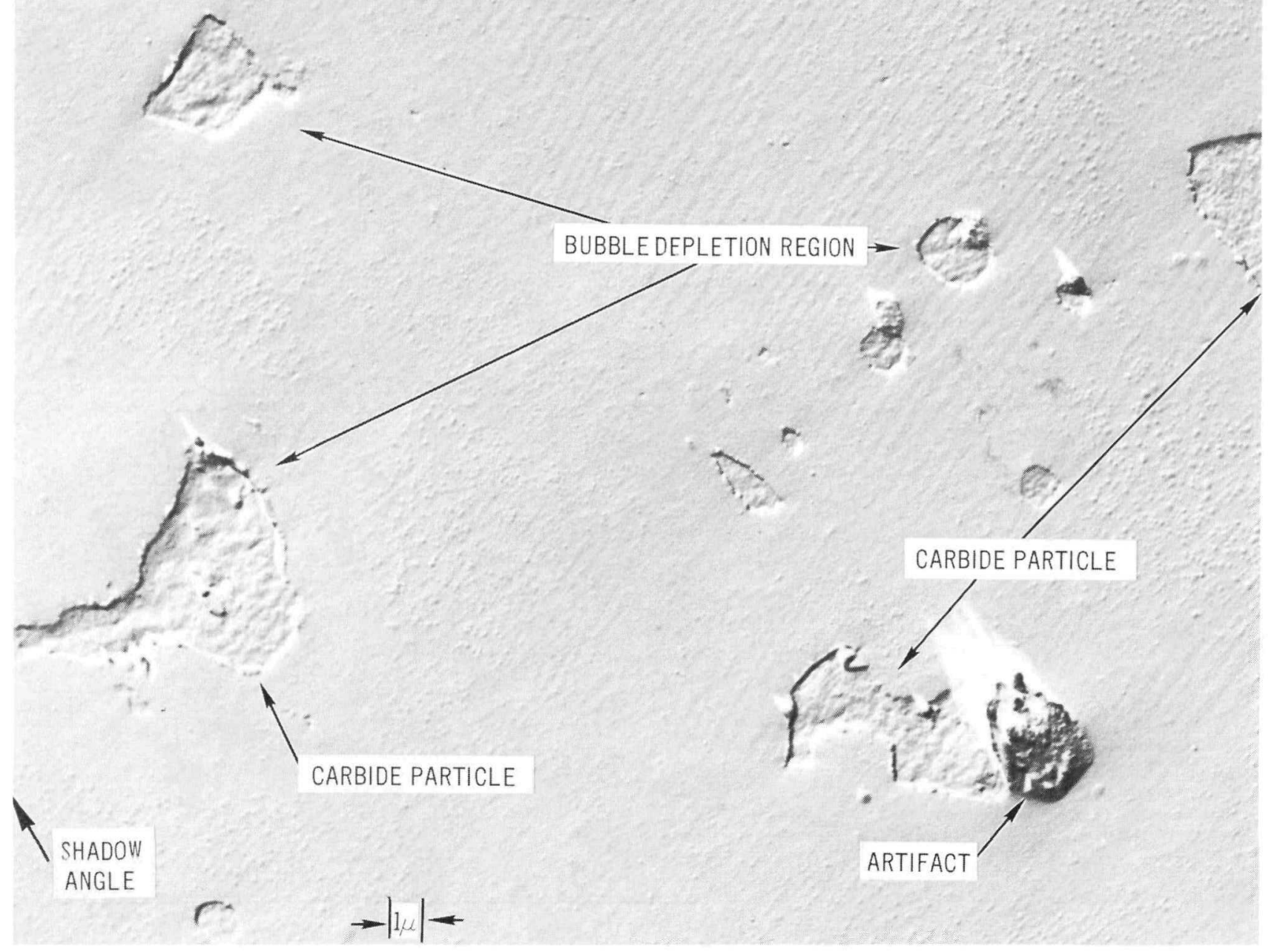

CRD (GP-1)

PHOTOGRAPHED AT 5,513X NO REDUCTION

Figure 13. Fission Gas Bubble Depletion Regions Around Large Particle Sites in the Element 519 Fuel Rod (6-1/2 in. from top) 


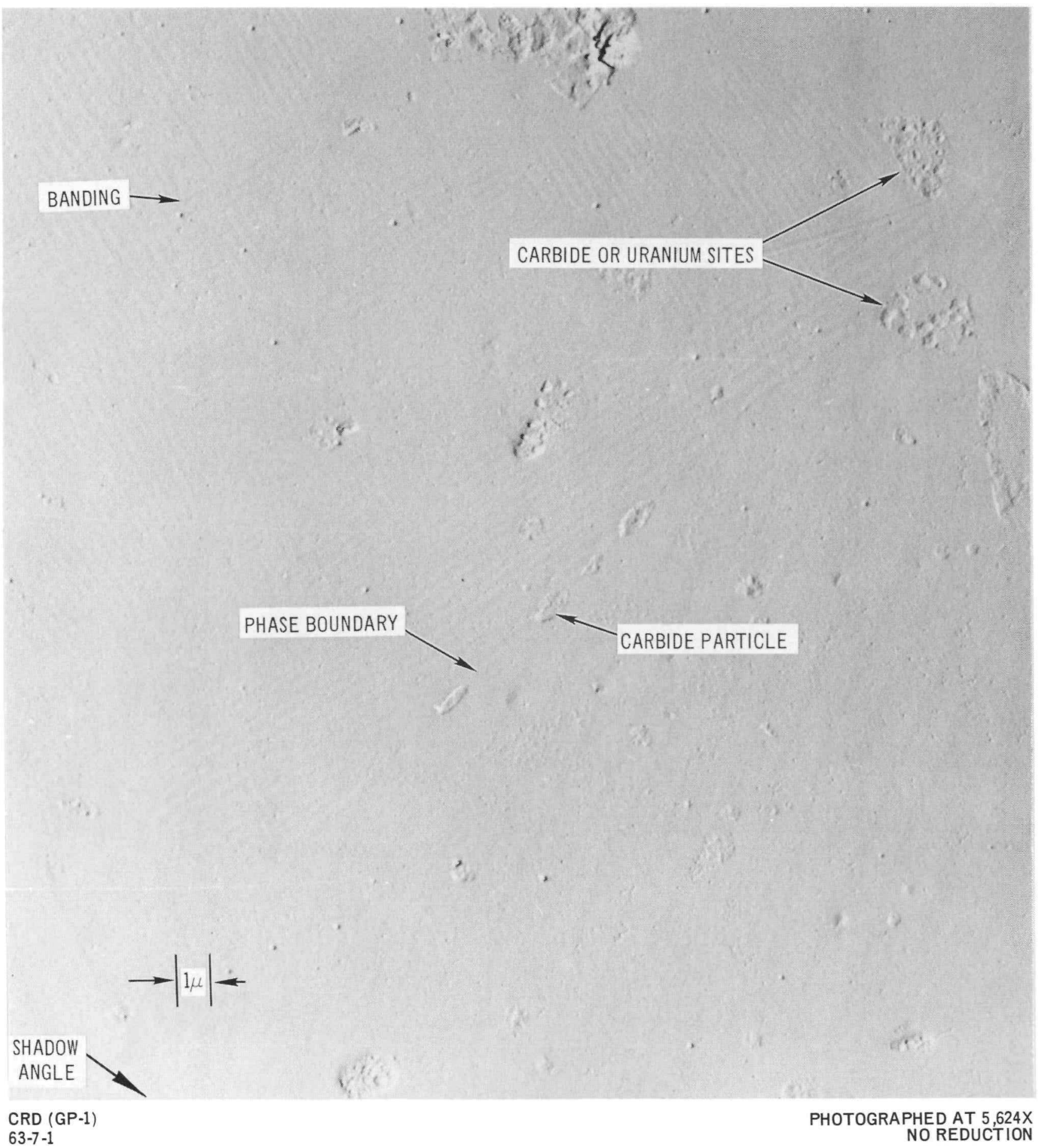

Figure 14. Phase Boundary in the Element 232 Fuel Rod

(5-3/4 in. from top)

NAA-SR - 12449

34 


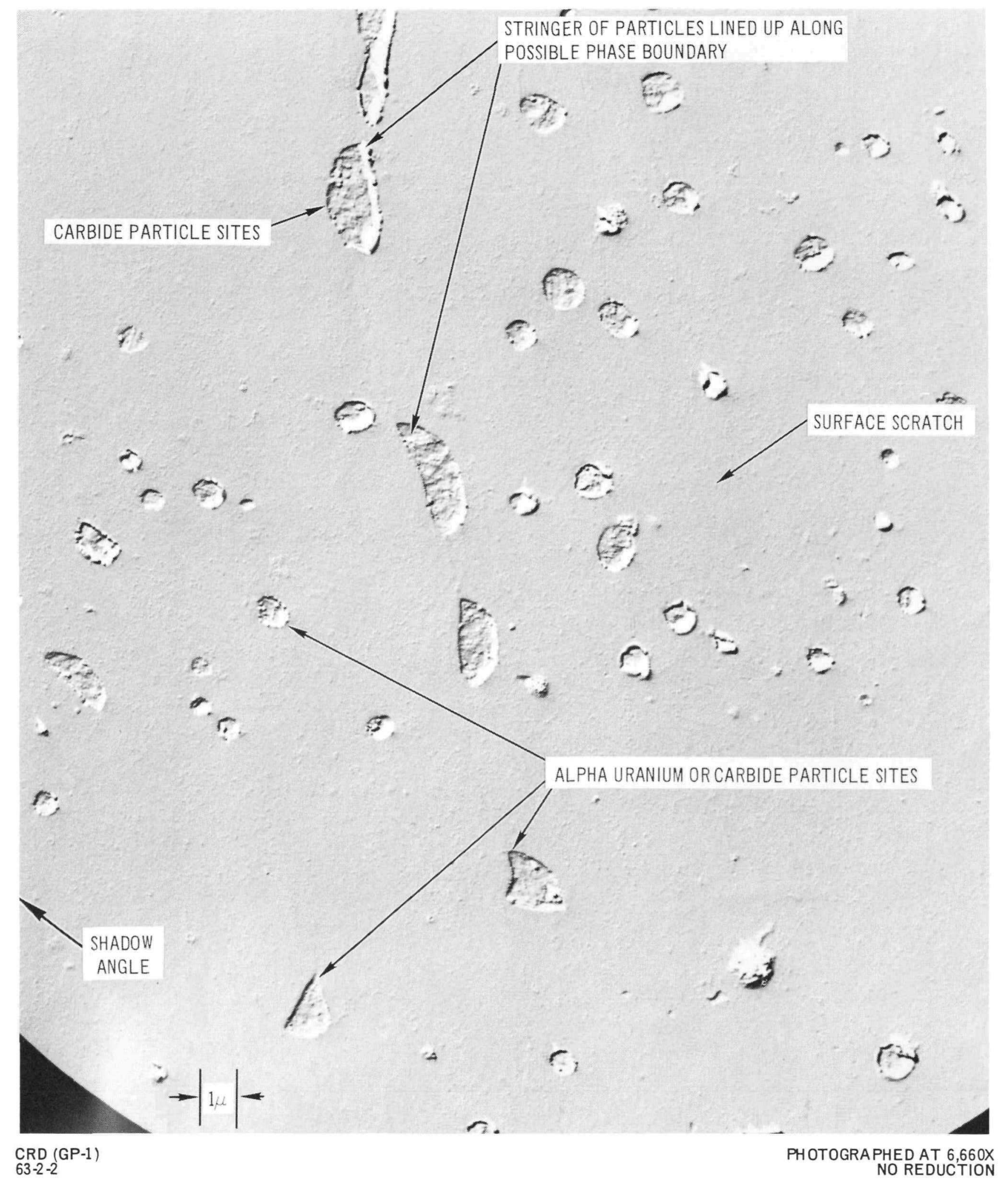

Figure 15. Possible Phase Boundary in the Element 398 Fuel Rod (11 in. from top)

$$
\text { NA A -SR - } 12449
$$




\section{CONFID EINIIAL}

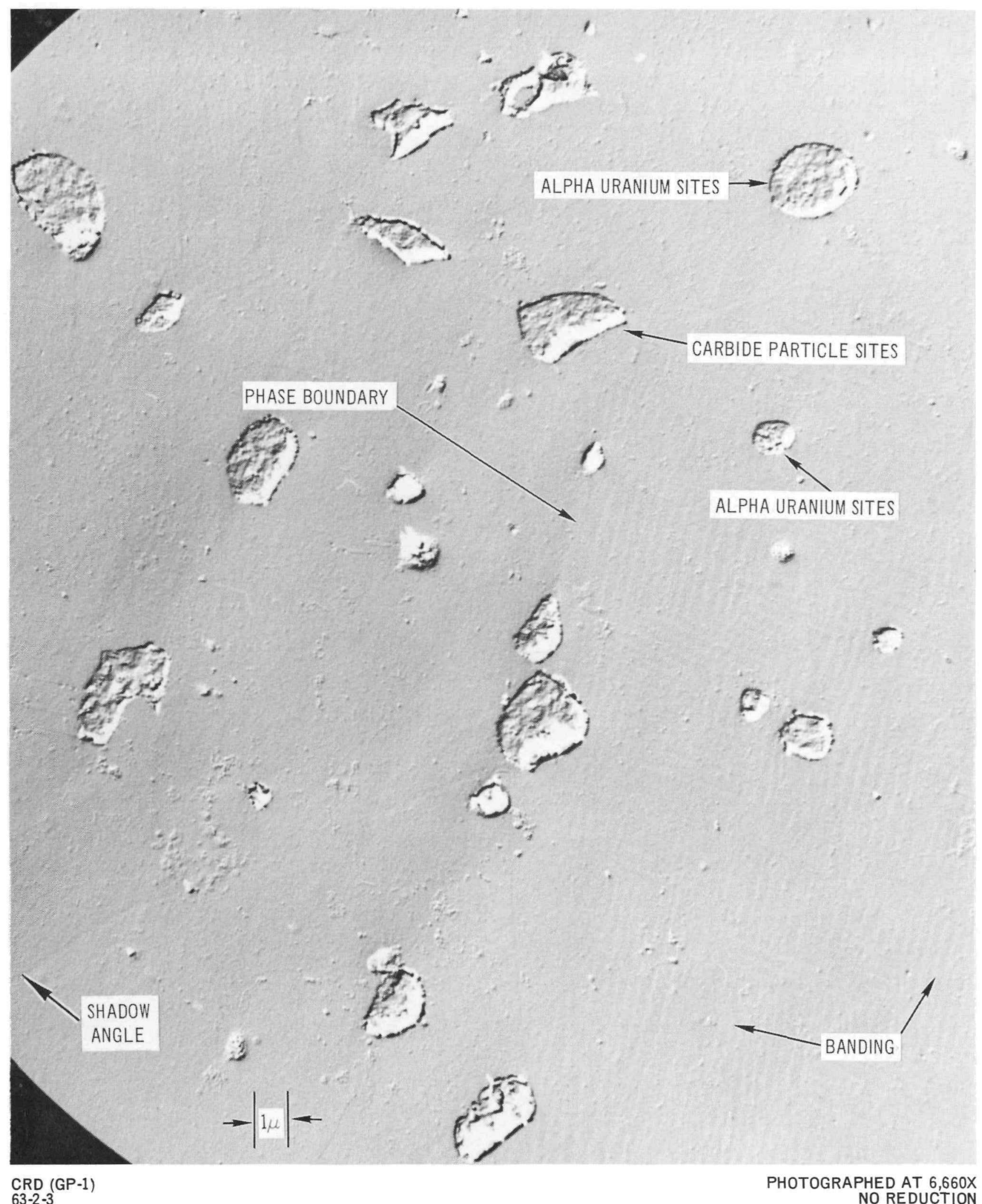

Figure 16. Surface Features in the Element 398 Fuel Rod (11 in. from top)

NAA -SR - 12449

36 


\begin{tabular}{|c|c|c|c|c|c|c|c|c|c|c|c|c|c|}
\hline \multirow{2}{*}{$\begin{array}{l}\text { Element } \\
\text { No. }\end{array}$} & \multirow{2}{*}{$\begin{array}{l}\text { Core } \\
\text { Location }\end{array}$} & \multirow{2}{*}{$\begin{array}{l}\text { Axial Location } \\
\text { on Rod } \\
\text { (Dist from Top) } \\
\text { (in.) }\end{array}$} & \multicolumn{2}{|c|}{ Fuel Rod Diam } & \multicolumn{2}{|c|}{ Volume Change } & \multirow{2}{*}{$\begin{array}{l}\text { Carbon } \\
\text { Content } \\
\text { (wt \%) }\end{array}$} & \multirow{2}{*}{$\left|\begin{array}{c}\text { Fuel } \\
\text { Burnup } \\
\text { (met.at.\%) }\end{array}\right|$} & \multirow{2}{*}{$\begin{array}{l}\text { Optical Metallography } \\
\text { Observations and } \\
\text { Post H/Zr Content }\end{array}$} & \multirow{2}{*}{$\begin{array}{l}\text { Remarks on Reason for } \\
\text { Choice of Sample }\end{array}$} & \multicolumn{3}{|c|}{ Electron Microscopy Observations } \\
\hline & & & $\begin{array}{c}\text { Diam } \\
\text { (in.) }\end{array}$ & $\underset{(\%)}{\Delta \mathrm{D} / \mathrm{D}}$ & $\begin{array}{l}\frac{\Delta v}{V} \\
(\%)\end{array}$ & $\underset{(\%)}{\frac{\Delta V}{V} \operatorname{Corr}_{2}}$ & & & & & $\begin{array}{l}\text { Micro- } \\
\text { cracks }\end{array}$ & $\begin{array}{c}\text { Fission Gas } \\
\text { Bubbles }\end{array}$ & Miscellaneous Observation \\
\hline IP3 $, 4,5$ & $\begin{array}{l}\text { Unirra- } \\
\text { diated }\end{array}$ & & & & & & & & $\begin{array}{l}\epsilon+\text { microcracks } \\
\mathrm{H} / \mathrm{Zr}=0.0 \text { to } 1.5\end{array}$ & $\begin{array}{l}\text { Control sample to } \\
\text { determine difference } \\
\text { between irradiated and } \\
\text { unirradiated. }\end{array}$ & Yes & No & $\begin{array}{l}\alpha U \text { sites, } \epsilon \text { twinning ghosts, } \\
\text { debris, carbide particles, } \\
\text { possible } \gamma^{\prime}, \epsilon \text { banding }+ \\
\text { fine sub-banding, boundary } \\
\text { line. }\end{array}$ \\
\hline $\begin{array}{r}\mathrm{E}-432 \\
\text { (intact) }\end{array}$ & VIII-29 & 3 & 0.5395 & +1.35 & +3.94 & +4.25 & 0.54 & 0.14 & $\begin{array}{l}\delta, \text { longit. mount } \\
\mathrm{H} / \mathrm{Zr}=1.61\end{array}$ & $\begin{array}{l}\text { Sample taken from peak } \\
\text { distortion area of fuel } \\
\text { rod-large } \Delta \mathrm{V} / \mathrm{V}\end{array}$ & Yes & Yes & $\begin{array}{l}\alpha U \text { sites, carbide particles, } \\
\epsilon \text { banding, phase boundary } \\
\text { with bubble depleted region } \\
\text { in the boundary and a round } \\
C \text { or U particles. }\end{array}$ \\
\hline $\begin{array}{l}\text { E-332 } \\
\text { (weld } \\
\text { failure) }\end{array}$ & VIII-25 & $1-1 / 2$ & 0.5210 & -2.15 & -5.83 & -0.39 & 0.55 & 0.10 & $\begin{array}{l}\alpha+\delta \text { eutectoid } \\
\mathrm{H} / \mathrm{Zr}=0.92\end{array}$ & $\begin{array}{l}\text { Gross dehydriding to } \\
\text { observe the structure }\end{array}$ & Yes & No & $\begin{array}{l}\alpha \text { U sites, possible two } \\
\text { phase region, possible } \\
\text { carbide particles. }\end{array}$ \\
\hline $\begin{array}{r}\mathrm{E}-188 \\
\text { (intact) }\end{array}$ & VIII-6 & $5-1 / 2$ & 0.5332 & +0.17 & -0.47 & +1.00 & 0.01 & 0.19 & $\begin{array}{l}\delta+\gamma^{\prime} \text { columnar struc- } \\
\text { ture, circum. cracks } \\
\text { at } 250 X, H / Z r=1.47, \\
\epsilon \text { ghost bands }\end{array}$ & $\begin{array}{l}\text { Large } \mathrm{H}_{2} \text { loss for } \\
\text { intact element }\end{array}$ & No & No & $\begin{array}{l}\alpha \text { U sites, carbide particles, } \\
\text { surface scratches, phase } \\
\text { boundary, } \epsilon \text { band ghosts. }\end{array}$ \\
\hline $\begin{array}{c}\mathrm{E}-378 \\
\text { (cracked) }\end{array}$ & IX -28 & 3 & 0.5430 & +1.99 & +4.56 & +4.98 & 0.34 & 0.15 & $\begin{array}{l}\text { 6, longit. mount, } \\
\text { faint banding at } 500 \mathrm{x}, \\
\text { crack in fuel, } \\
\mathrm{H} / \mathrm{Zr}=1.58\end{array}$ & $\begin{array}{l}\text { Sample taken from peak } \\
\text { distortion area of fuel } \\
\text { rod }\end{array}$ & No & No & $\begin{array}{l}\alpha \text { U sites, carbide particles. } \\
\text { Poor replicas, insuffidient } \\
\text { detail for analysis. }\end{array}$ \\
\hline $\begin{array}{c}E-378 \\
\text { (cracked) }\end{array}$ & IX -28 & $11-1 / 2$ & 0.5362 & +0.71 & +0.91 & +1.72 & 0.34 & 0.14 & $\epsilon, \mathrm{H} / \mathrm{Zr}=1.72$ & $\begin{array}{l}\text { Region of suspected } \\
\delta \text { to } \epsilon \text { transformation, } \\
\text { high final } \mathrm{H} / \mathrm{Zr}\end{array}$ & & & $\begin{array}{l}\text { Poor replicas, insufficient } \\
\text { detail for analysis. }\end{array}$ \\
\hline $\begin{array}{c}\text { E-111 } \\
\text { (cracked) }\end{array}$ & IX -42 & $11-1 / 2$ & 0.5376 & +0.99 & +1.45 & +1.50 & 0.01 & 0.14 & $\begin{array}{l}\epsilon, \text { large voids } \\
\mathrm{H} / \mathrm{Zr}=1.73\end{array}$ & $\begin{array}{l}\text { Sample taken from peak } \\
\text { distortion area of fuel } \\
\text { rod, region of sus- } \\
\text { pected oto } 6 \text { transfor- } \\
\text { mation, high final } \\
\mathrm{H} / \mathrm{Zr} \text {, }\end{array}$ & No & No & $\begin{array}{l}\alpha U \text { sites, carbide particles, } \\
\epsilon \text { banding. }\end{array}$ \\
\hline $\begin{array}{r}\mathrm{E}-232 \\
\text { (intact) }\end{array}$ & VI-24 & $5-3 / 4$ & 0.5376 & +1.01 & +3.25 & +4.02 & 0.54 & 0.21 & $\begin{array}{l}\delta \text { phase with banding, } \\
\mathrm{H} / \mathrm{Zr}=1.56\end{array}$ & $\begin{array}{l}\text { Region of suspected } \delta \\
\text { to } \delta+\beta \text { transforma- } \\
\text { tion, large } \Delta \mathrm{V} / \mathrm{V}\end{array}$ & No & Possible & $\begin{array}{l}\alpha U \text { sites, carbide particles, } \\
\epsilon \text { banding, phase boundary, } \\
\text { possible bubble depletion } \\
\text { zone around phase boundary } \\
\text { and large particles (magnif. } \\
\text { too low for positive identifi- } \\
\text { cation). }\end{array}$ \\
\hline
\end{tabular}

Table 2 (Sheet 1 of 2) Electron Microscopy Observations
of Irradiated SNAP8 Fuel Samples 


\section{BLANK}




\begin{tabular}{|c|c|c|c|c|c|c|c|c|c|c|c|c|c|}
\hline \multirow{2}{*}{$\begin{array}{l}\text { Element } \\
\text { No. }\end{array}$} & \multirow{2}{*}{$\begin{array}{c}\text { Core } \\
\text { Location }\end{array}$} & \multirow{2}{*}{$\begin{array}{l}\text { Axial Location } \\
\text { on Rod } \\
\text { (Dist from Top) } \\
\text { (in.) }\end{array}$} & \multicolumn{2}{|c|}{ Fuel Rod Diam } & \multicolumn{2}{|c|}{ Volume Change } & \multirow{2}{*}{$\begin{array}{c}\text { Carbon } \\
\text { Content } \\
\text { (wt \%) }\end{array}$} & \multirow{2}{*}{$\left|\begin{array}{c}\text { Fuel } \\
\text { Burnup } \\
\text { (met.at.\%) }\end{array}\right|$} & \multirow{2}{*}{$\begin{array}{l}\text { Optical Metallography } \\
\text { Observations and } \\
\text { Post H/Zr Content }\end{array}$} & \multirow{2}{*}{$\begin{array}{c}\text { Remarks on Reason for } \\
\text { Choice of Sample }\end{array}$} & \multicolumn{3}{|c|}{ Electron Microscopy Observations } \\
\hline & & & $\begin{array}{l}\text { Diam } \\
\text { (in.) }\end{array}$ & $\underset{(\%)}{\Delta \mathrm{D} / \mathrm{D}}$ & $\begin{array}{l}\frac{\Delta V}{V} \\
(\%)\end{array}$ & $\frac{\Delta V}{V} \underset{(\%)}{\operatorname{Corr}}$ & & & & & $\begin{array}{l}\text { Micro- } \\
\text { cracks }\end{array}$ & $\begin{array}{l}\text { Fission Gas } \\
\text { Bubbles }\end{array}$ & Miscellaneous Observations \\
\hline $\begin{array}{c}\mathrm{E}-519 \\
\text { (cracked) }\end{array}$ & IV-1 & $6-1 / 2$ & 0.5415 & +1.76 & +3.72 & +4.58 & 0.50 & 0.23 & $\begin{array}{l}\delta+\gamma^{\prime} \text { with faint } \epsilon \\
\text { banding ghosts, cir- } \\
\text { cum. cracks at } 250 \mathrm{X}, \\
\mathrm{H} / \mathrm{Zr}=1.54\end{array}$ & $\begin{array}{l}\text { Sample was taken from } \\
\text { peak distortion area of } \\
\text { rod, region of sus- } \\
\text { pected } \delta \text { to } \delta+\beta \text { trans., } \\
\text { large } \Delta V / V\end{array}$ & No & Yes & $\begin{array}{l}\alpha U \text { sites, carbide particles } \\
\text { bubble depletion zone around } \\
\text { large particles, } \epsilon \text { banding } \\
\text { ghosts, possible former } \\
\text { grain boundary. }\end{array}$ \\
\hline $\begin{array}{c}\text { E-398 } \\
\text { (cracked) }\end{array}$ & \begin{tabular}{|l|} 
IV -13 \\
NAA
\end{tabular} & $15-1$ & 0.5360 & +0.73 & +0.54 & +0.91 & 0.40 & 0.17 & $\begin{array}{l}\delta \text { with faint } \epsilon \text { banding, } \\
\mathrm{H} / \mathrm{Zr}=1.60\end{array}$ & $\begin{array}{l}\text { Substituted for request- } \\
\text { ed sample which could } \\
\text { not be obtained }\end{array}$ & No & No & $\begin{array}{l}\alpha \text { U sites, carbide particles, } \\
\epsilon \text { banding, phase boundaries }\end{array}$ \\
\hline $\begin{array}{c}\text { IS-4 } \\
\text { (intact) }\end{array}$ & & 2 & 0.5327 & +0.98 & +4.16 & +4.30 & 0.40 & 0.41 & $\epsilon, \mathrm{H} / \mathrm{Zr}=1.64$ & $\begin{array}{l}\text { Large } \Delta V / V \text {, only fuel } \\
\text { rod with } 0.4 \text { w/o } \mathrm{C} \text { in } \\
\text { expt. }\end{array}$ & Yes & Yes & $\begin{array}{l}\alpha U \text { sites, } \epsilon \text { banding, bound- } \\
\text { ary lines, bubble depletion } \\
\text { region around large parti- } \\
\text { cles, sample may be at } \\
\text { point of incipient gross } \\
\text { swelling, carbide particles. }\end{array}$ \\
\hline $\begin{array}{l}\text { IS-7 } \\
\text { (intact) }\end{array}$ & & 2 & 0.5312 & +0.73 & +2.94 & +4.11 & 0.10 & 0.41 & $\begin{array}{l}\delta \text { phase with } \gamma^{\prime} \text { at } \\
\text { center, faint banding } \\
\text { at edge, cracks from } \\
\text { center to edge, } \\
\mathrm{H} / \mathrm{Zr}=1.50\end{array}$ & Large $\Delta \mathrm{V} / \mathrm{V}$ & No & Yes & $\begin{array}{l}\alpha \mathrm{U} \text { sites, } \epsilon \text { banding, carbide } \\
\text { particles, bubble depletion } \\
\text { region around large parti- } \\
\text { cles, poor replicas. }\end{array}$ \\
\hline $\begin{array}{l}\text { IS-8 } \\
\text { (intact) }\end{array}$ & & 2 & 0.5315 & -0.43 & +0.74 & +2.08 & 0.10 & 0.43 & $\begin{array}{l}\text { Center and mid-radius } \\
\text { area was } \delta+\gamma^{\prime} \text {, edge } \\
\text { was } \delta \text { with faint band- } \\
\text { ing, large cracks } \\
\text { from edge to center, } \\
\mathrm{H} / \mathrm{Zr}=1.45\end{array}$ & $\begin{array}{l}\text { Large } \Delta \mathrm{V} / \mathrm{V}, \text { large } \mathrm{H}_{2} \\
\text { loss of }-0.37 \mathrm{H} / \mathrm{Zr}\end{array}$ & No & Yes & $\begin{array}{l}\alpha U \text { sites, } \epsilon \text { banding and fine } \\
\text { sub-banding, carbide parti- } \\
\text { cles, phase boundary, } \gamma^{\prime} \\
\text { particle, no apparent bubble } \\
\text { depletion around large par- } \\
\text { ticles as was observed on } \\
\text { other samples. }\end{array}$ \\
\hline
\end{tabular}

Table 2 (Sheet 2 of 2)

Electron Microscopy Observations of Irradiated SNAP 8 Fuel Samples 


\section{BLANK}


delta, delta plus epsilon, epsilon phase boundary with moderate fuel swelling of approximately $1.50 \%$. Both samples examined had a postirradiation hydrogen content greater than $1.70 \mathrm{H} / \mathrm{Zr}$. Replicas obtained from the element 378 fuel at $11-1 / 2$ in. from the top were not of good quality and gave insufficient detail for analysis.

Optical metallography on the fuel from element 111 revealed epsilon phase with voids in the fuel. The replica was taken from the peak distortion area of the rod. No evidence of microcracking or fission gas bubbles was observed (at $6000 \mathrm{X}$ magnification, the limit of resolution is $1000 \AA$ ). Figures 17 and 18 show the surface features of the fuel. Epsilon cross banding, uranium sites, and carbide sites were common.

The remaining two fuel wafers replicated were chosen as a result of high hydrogen loss from the fuel. Element 332 exhibited gross dehydriding due to a weld failure. Element 188 was examined as it was the only intact element to exhibit dehydriding down to $1.47 \mathrm{H} / \mathrm{Zr}$. Metallog raphy of this fuel showed delta plus gamma prime with banding ghosts at 5-1/2 in. from the top. Metallography of rod 332, 1-1/2 in. from the top, showed an alpha-delta eutectoid composition with an $\mathrm{H} / \mathrm{Zr}$ of 0.92 .

Replication of the element 188 fuel revealed the normal particle sites and banding. No microcracks or fission gas bubbles were observed (see Figure 19). Replication of the fuel surface from element 332 showed the normal particle sites with some microcracking. Typical surface features are shown in Figures 20 and 21. A summary of the data is presented in Table 2.

\section{NAA 115-1 FUEL ANALYSIS}

The three fuel surfaces replicated were from elements IS-4, IS-7, and IS-8. All three surfaces were from regions of large volume changes ranging from 2.08 to $4.30 \%\left(\mathrm{H}_{2}\right.$ corrected). These samples experienced a fuel burnup of 0.41 to 0.43 met. at. $\%{ }^{(6)}$ Optical metallographic examination revealed delta plus gamma prime phases in IS -7 and -8 with predominantly delta plus epsilon phase in IS-4. Also, radial cracks were observed in IS-7 and -8. The postirradiation hydrogen content ranged from 1.45 in IS-8 to 1.64 in IS-4. 


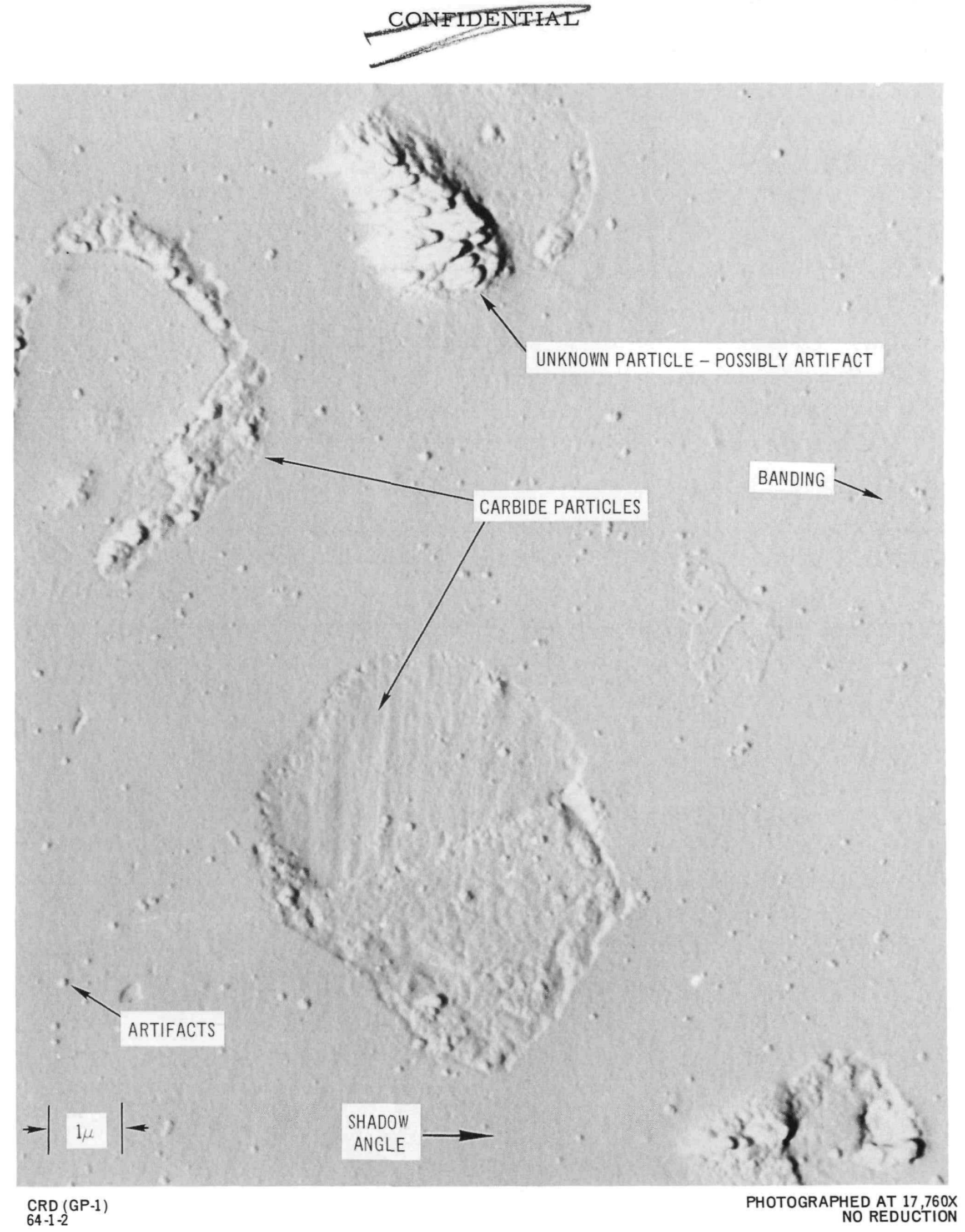

Figure 17. Carbide Particles in the Element 111 Fuel Rod (11-1/2 in. from top)

$$
\begin{gathered}
\text { NAA -SR }-12449 \\
42
\end{gathered}
$$



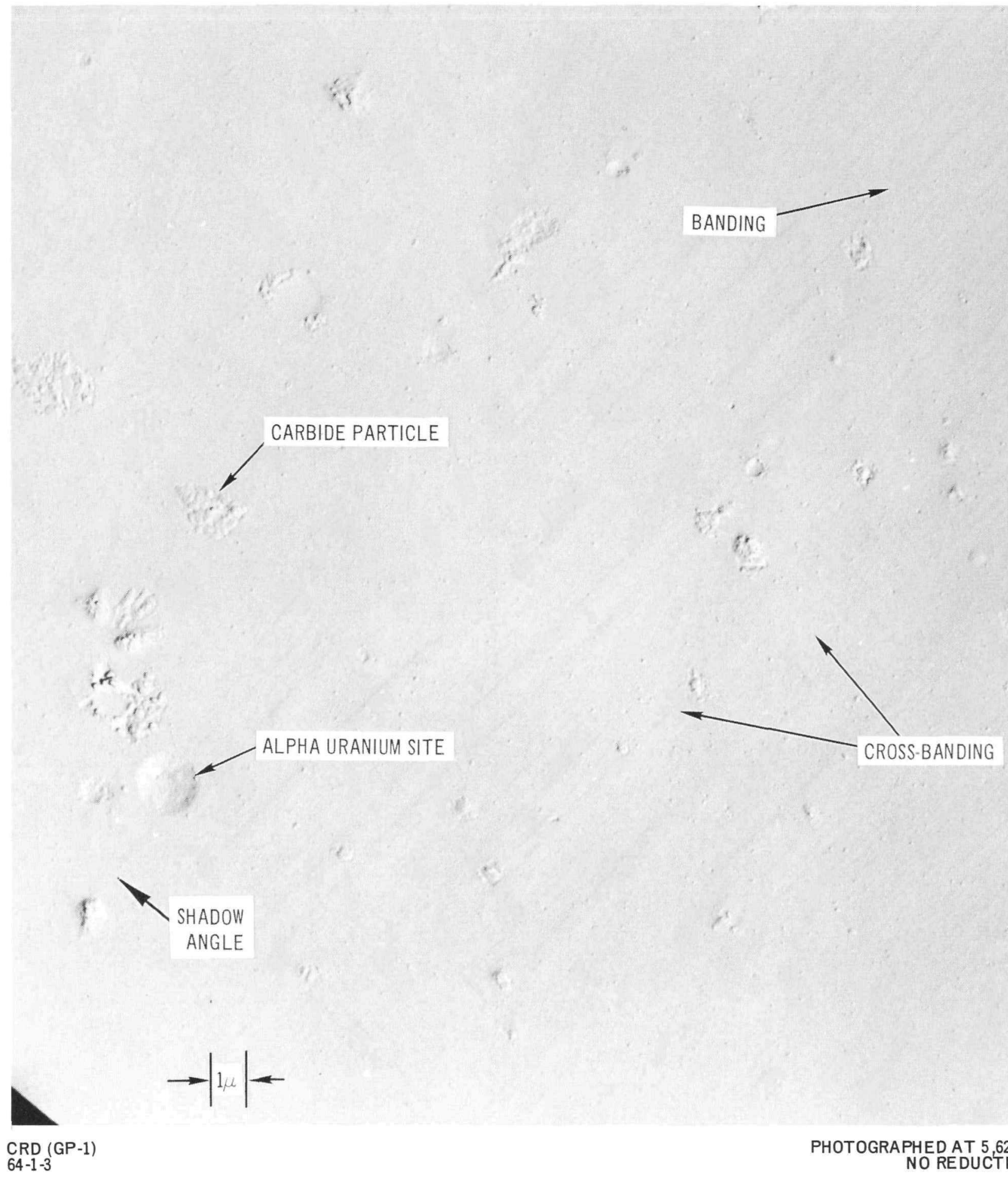

Figure 18. Surface Features in the Element 111 Fuel Rod (11-1/2 in. from top)

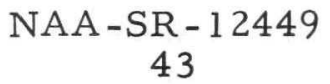




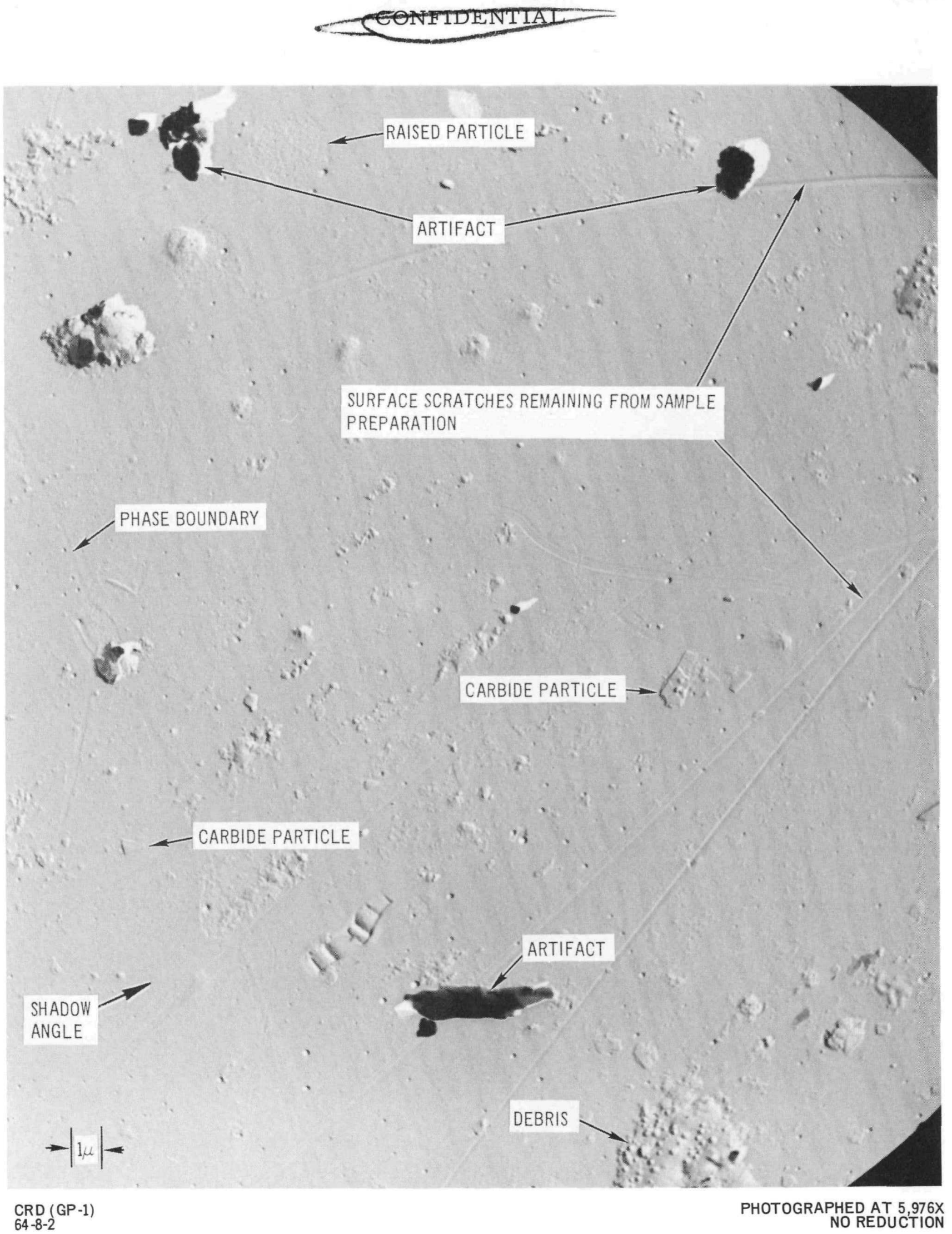

Figure 19. Surface Features in the Element 188 Fuel Rod (5-1/2 in. from top)

NAA -SR - 12449

44 


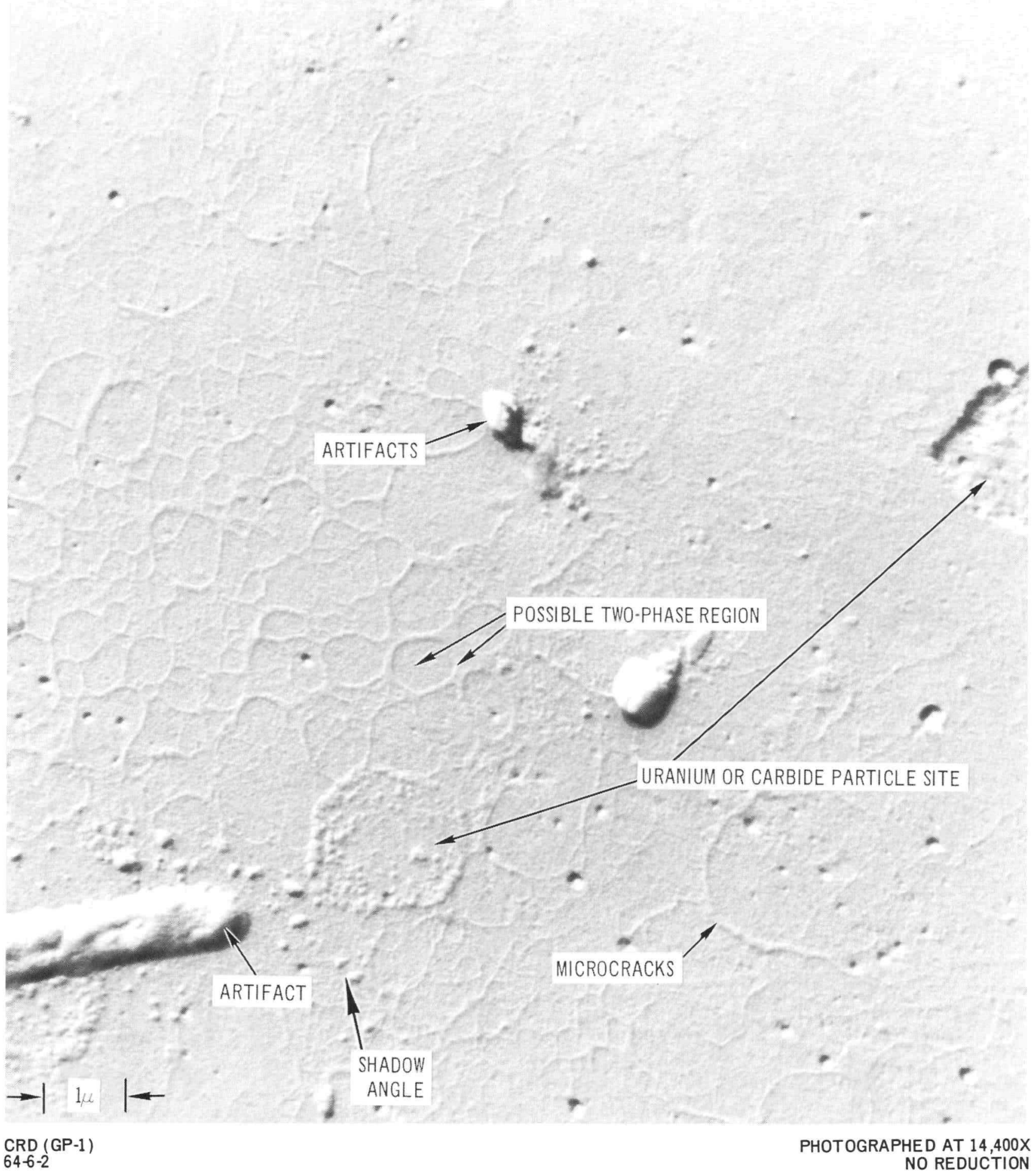

Figure 20. Possible Two-Phase Region in the Element 332 Fuel Rod ( $1-1 / 2$ in. from top)

NAA-SR - 12449 


\section{GONEIDENTIAL}

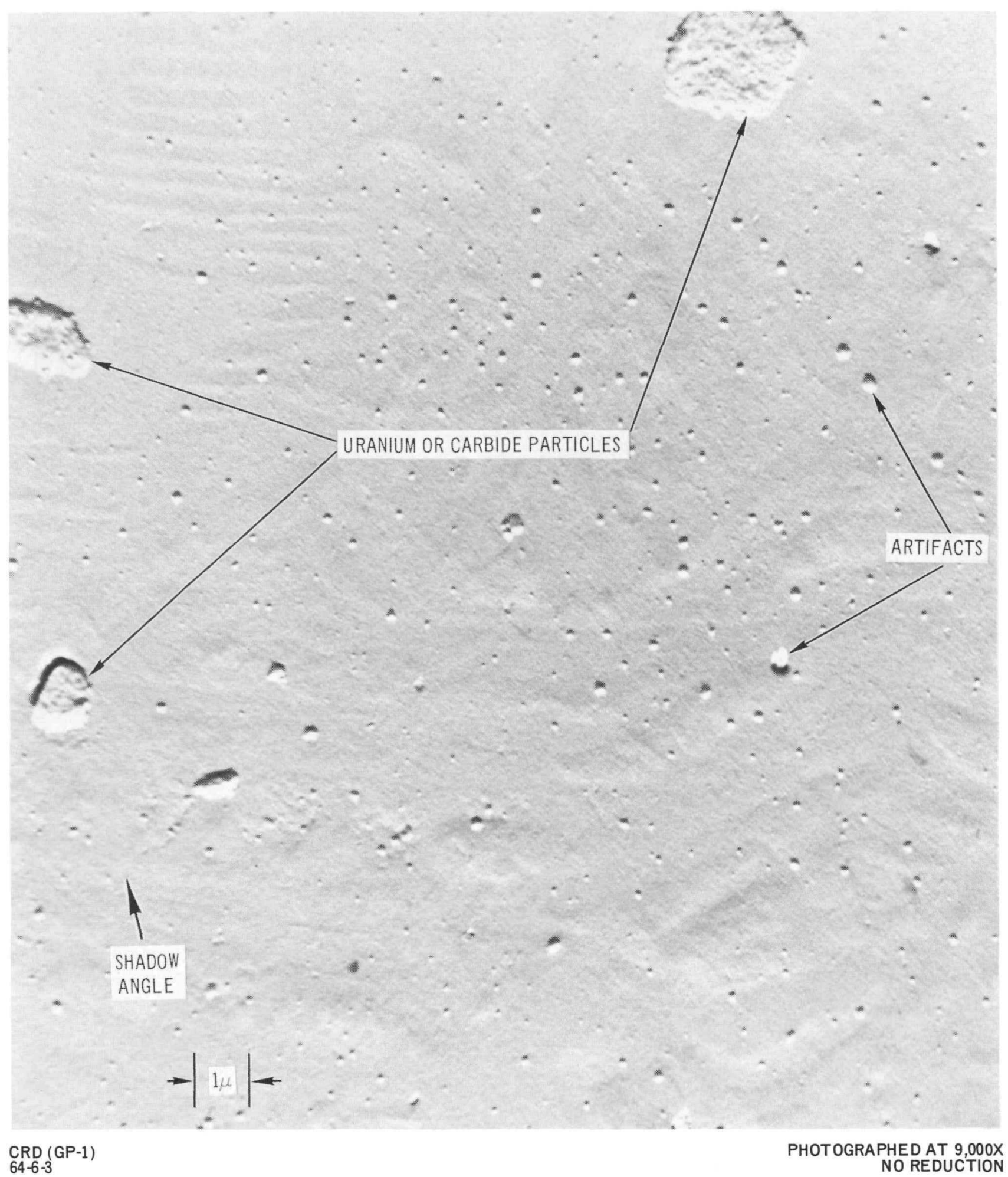

Figure 21. Surface Features of the Element 332 Fuel Rod ( $1-1 / 2$ in. from top) 
Electron microscopy indicated the presence of fission gas bubbles in all three fuel rods; however, microcracks were observed only in IS-4. Alpha uranium and carbide sites, phase boundary lines, and banding were common in all three replicas. Fission gas bubble depletion regions were observed around the large particle sites and phase boundaries in IS-4 and IS-7. This depletion region was not found in IS-8, which experienced half the volume change of the other two fuel samples.

Surface features of IS-4 fuel are shown in Figures 22 to 24 . A typical phase boundary is shown in Figure 24.

Replication of the fuel surface from IS-7 was generally poor; however, Figure 25 shows some of the surface features from this fuel rod.

Typical surface features of IS-8 are shown in Figures 26 to 29. Very fine banding can be seen in Figure 27. Figure 28 shows what may be some fission gas bubble agglomeration, but this cannot be positively ascertained from the photograph. A similar phenomenon has been observed in lower magnification photographs on irradiated fuel from other samples as shown in Figures 15 and 16. Examination of the unirradiated fuel replicas did not show this same characteristic. This possible agglomeration may also be the result of chemica] attack by the etchant during sample preparation. Irradiated fuel is more sus ceptible to chemical attack than unirradiated fuel. A typical phase boundary and a gamma prime particle are shown in Figure 29. A summary of the electron microscope observations are tabulated in Table 2.

Fission gas bubble size and bubble density measurements were taken from the replica photographs. The results of these measurements are discussed in the next section of the report.

\section{FISSION GAS BUBBLE ANALYSIS}

Representative photographs were selected from those fuel surfaces which exhibited fission gas bubbles. From these photographs, the bubble volume fraction and bubble density in terms of bubbles/cc were calculated. Also, representative length measurements were taken of the distance between particles and the start of fission gas bubbles with the larger uranium and carbide particles. These large particles may act as trapping sites for the fission gas bubbles.

NAA -SR - 12449 


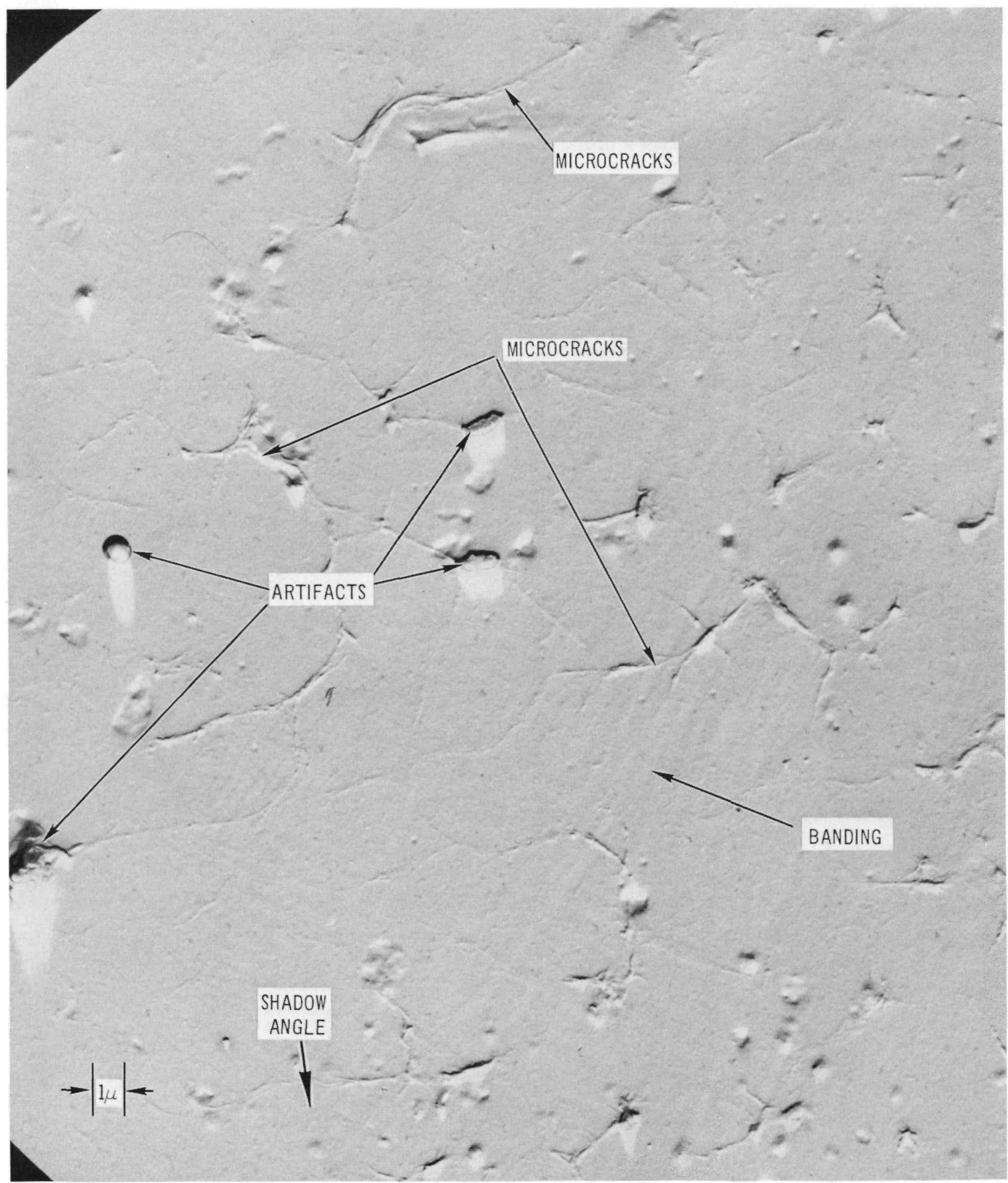

Figure 22. Microcracks in the IS-4 Fuel Rod

NAA -SR - 12449 


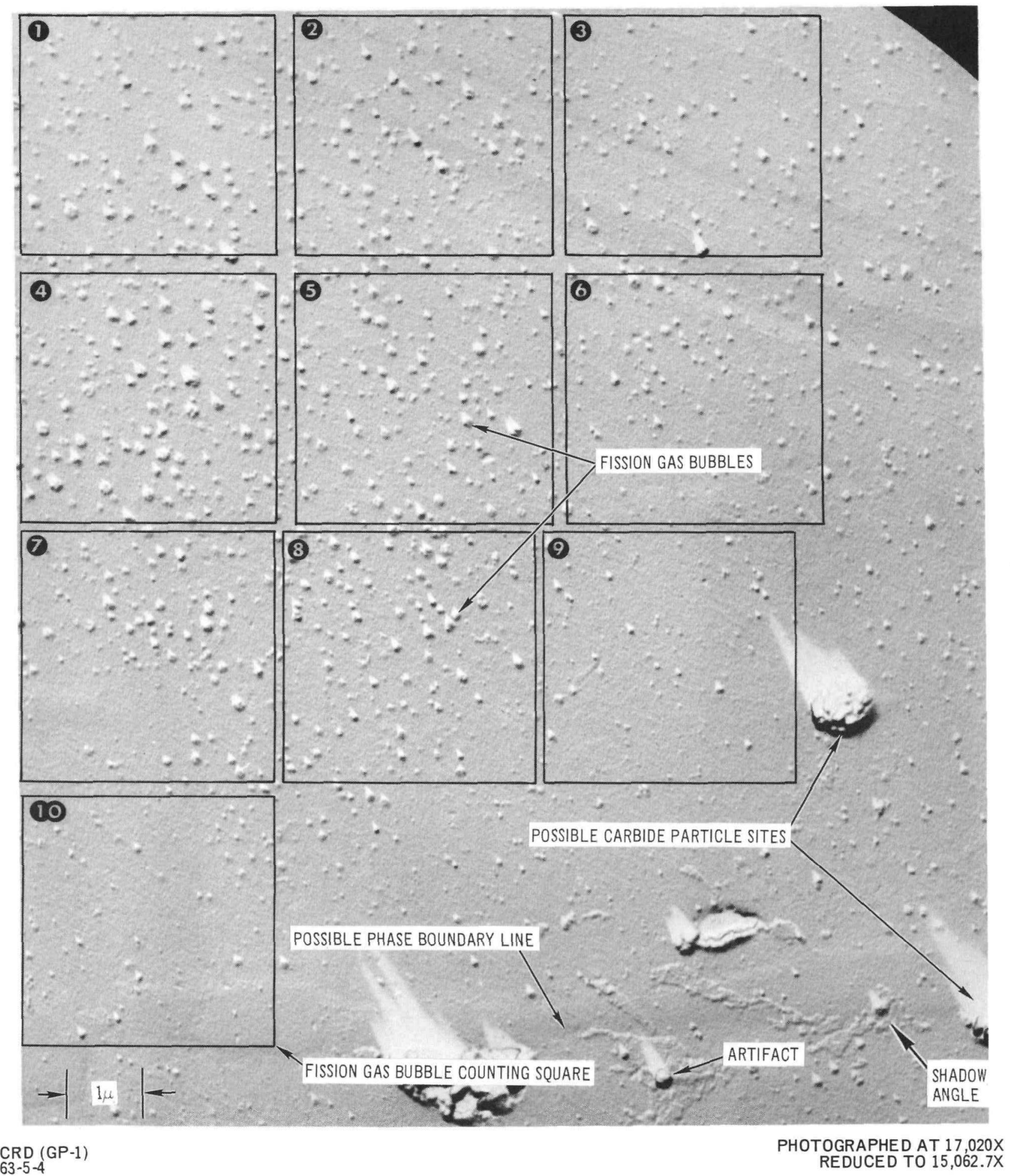

Figure 23. Fission Gas Bubbles in the IS-4 Fuel Rod 


\section{BLANK}




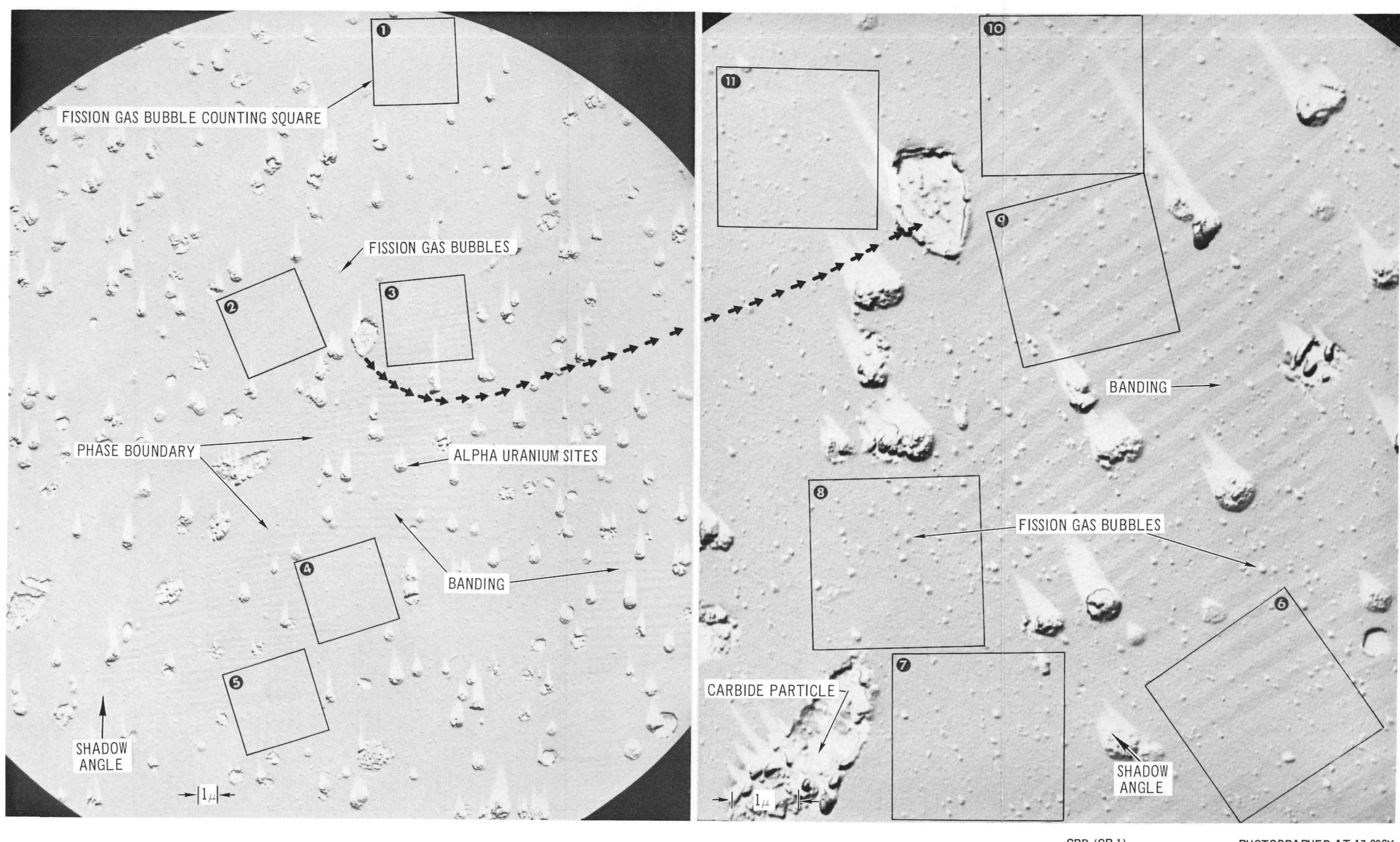

Figure 24. Phase Boundary in the IS-4 Fuel Rod 


\section{BLANK}




\section{DIDENTAE}

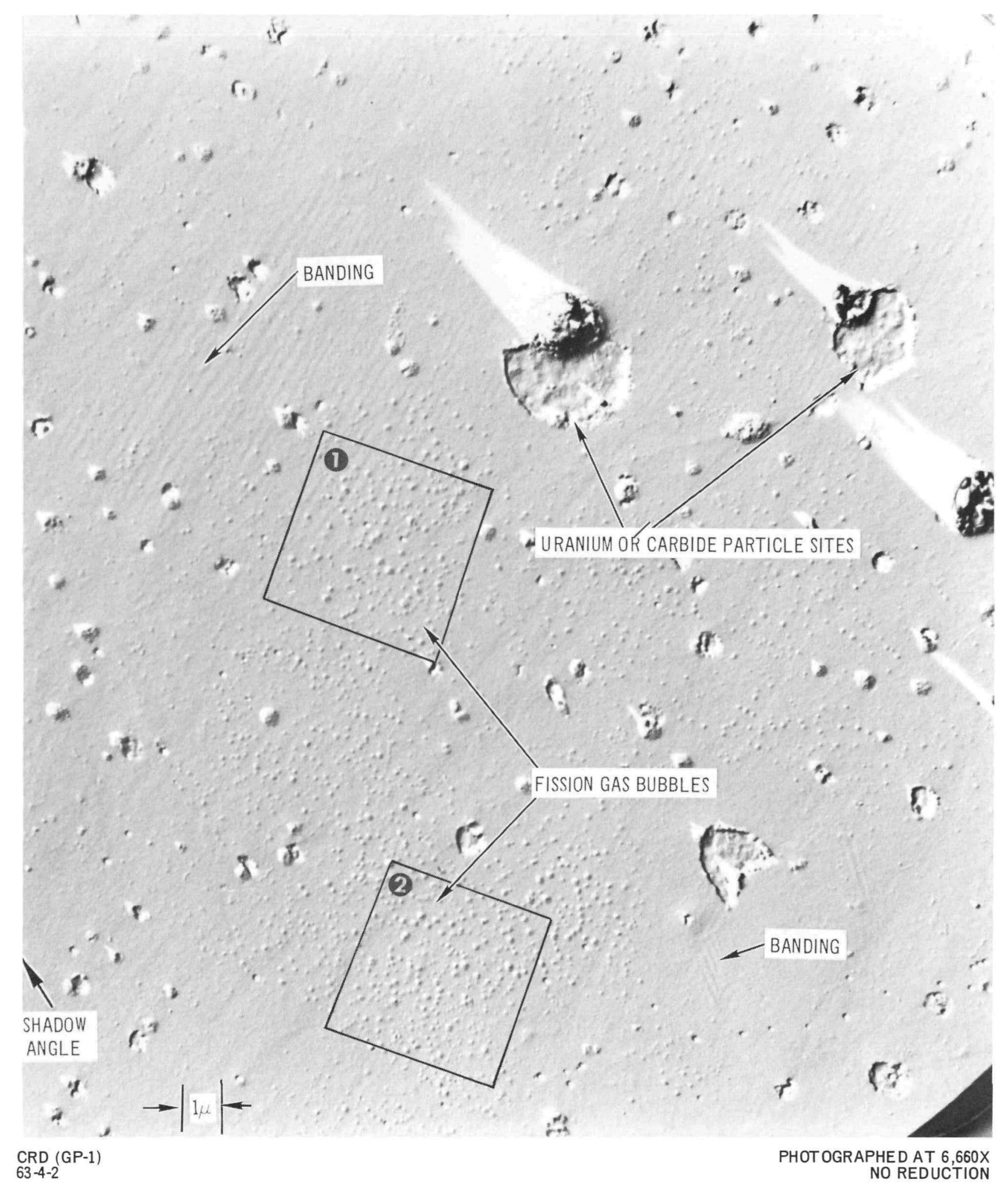

Figure 25. Surface Features of the IS-7 Fuel Rod 

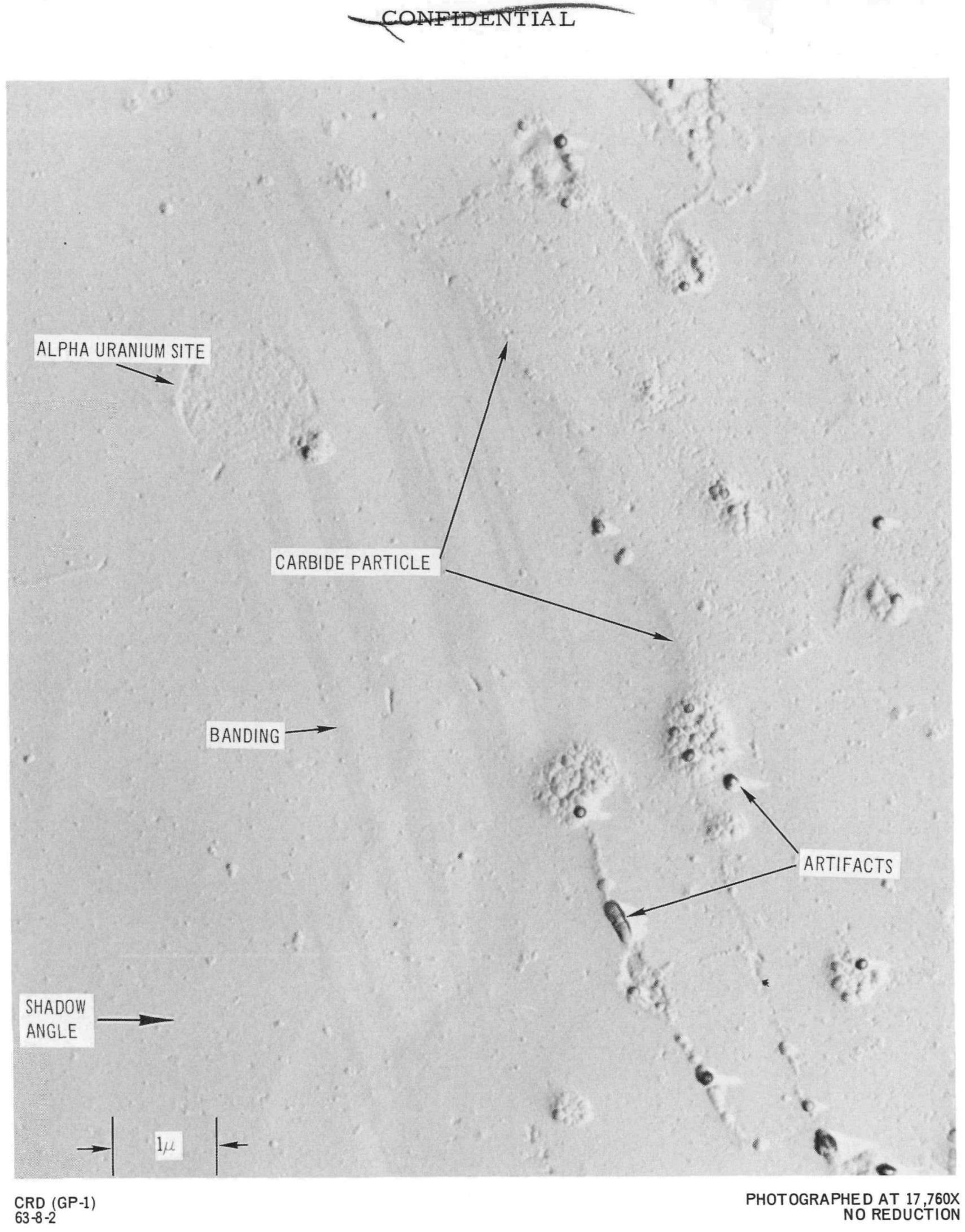

Figure 26. Carbide Particle in the IS- 8 Fuel Rod

NAA -SR - 12449 


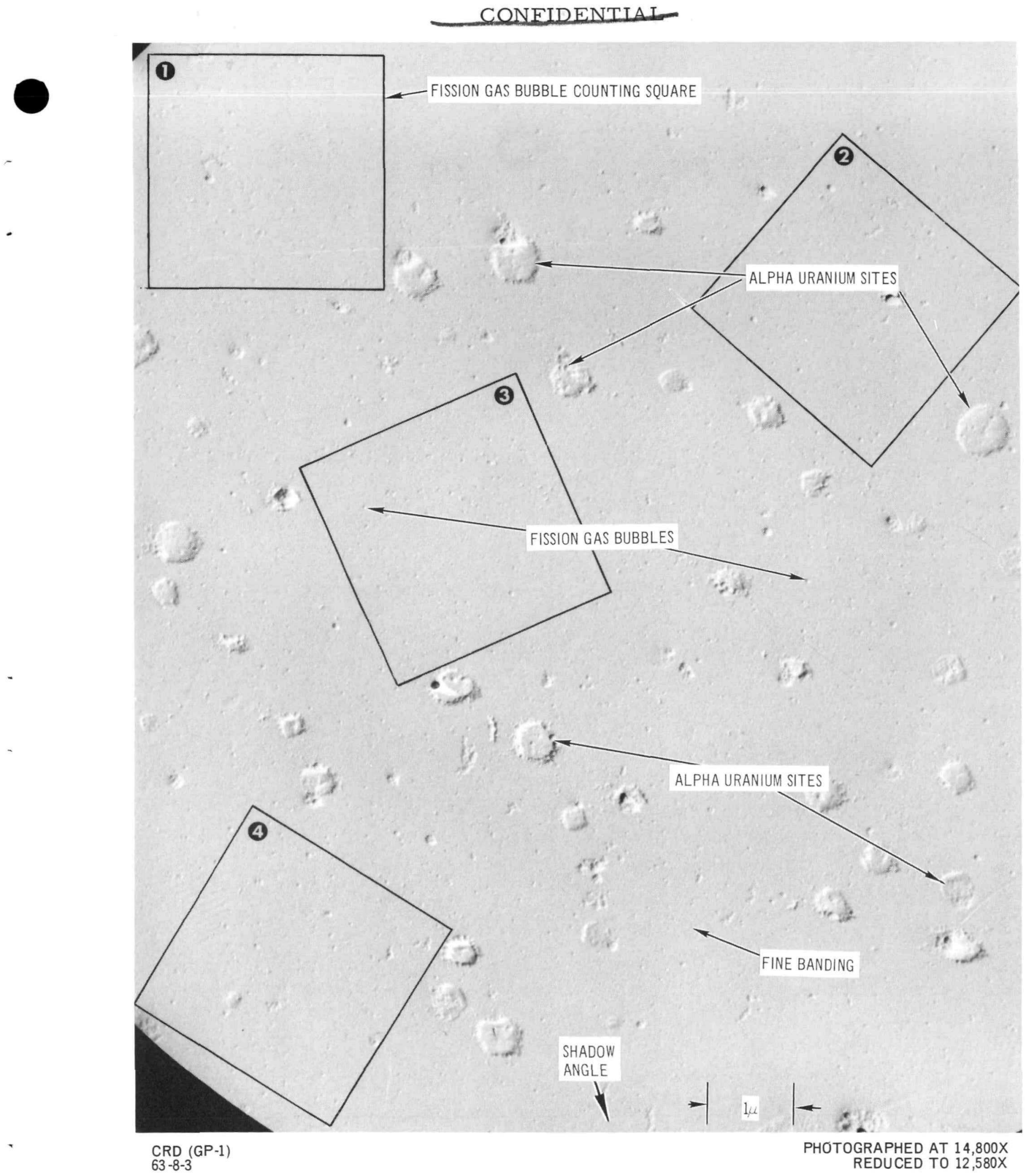

Figure 27. Fine Banding in the IS-8 Fuel Rod

NAA-SR - 12449

55 


\section{COAFIDENTIAL}

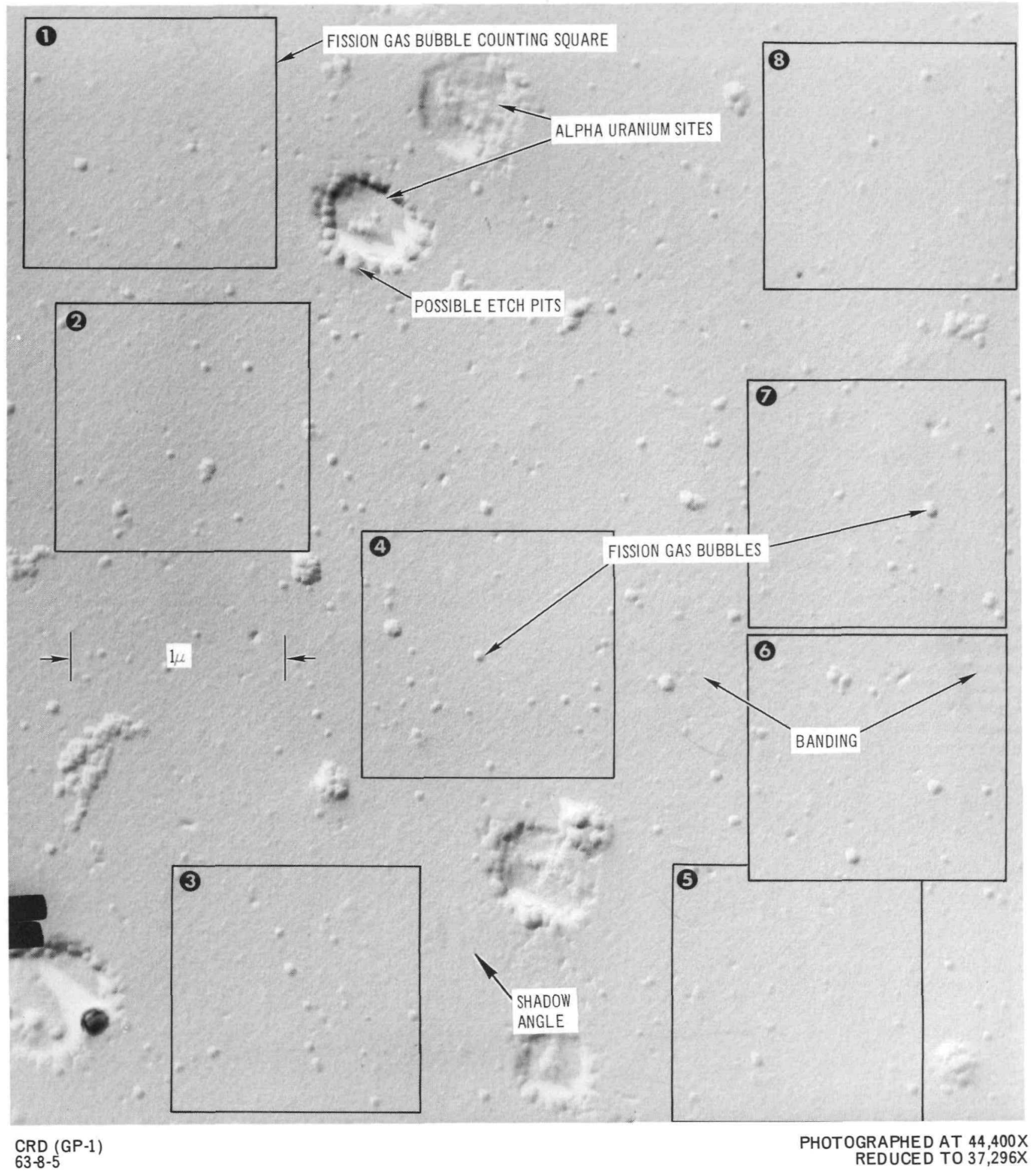

Figure 28. Fission Gas Bubbles in the IS-8 Fuel Rod 



\section{BLANK}


The bubbles were counted at various locations on a photograph by inscribing a square on the photograph and physically counting the number of bubbles within the square. This was done by using a quantitative metallographic particle size counter. To simplify the subsequent calculation, the assumptions were made that all particles on any one photograph were of uniform diameter, ${ }^{(6)}$ the bubble distribution in the inscribed square was uniform, and a cube formed by projecting the square into the fuel surface allowed calculation of the bubble volume fraction by assuming the volume fraction was equal to area fraction. From this information, the contribution of the formation of fission gas bubbles to the observed fuel swelling can be determined. The number of fission gas bubbles per unit volume was also calculated in a manner similar to that reported by Kramer. ${ }^{(7)}$

All bubble counts were taken in areas unaffected by void depletion zones around particle sites. From 4 to 10 squares were counted in each photograph measured. The location and identificiation of each counting square is shown in Figures 8 through 29 on those figures which had fission gas bubbles. Some of the measurements were made on photographs not reproduced in the report. Table 3 is a tabulation of the fission gas bubble volume fractions and bubble density for each counting square. The volume fractions are tabulated as percent of the volume due to bubbles. Measurements were taken on the five fuel samples which indicated positively the presence of fission gas bubbles.

A summary of the average bubble volume fraction as compared to the measured volumetric increases on the fuel is presented in Table 4. Due to the bubble depletion regions around particle sites and grain boundaries, the bubble volume fractions determined from the counting squares are not necessarily representative of volume fractions for the fuel since the counting squares were selected in regions away from particle sites and grain boundaries. Thus, a visual estimate was made of the fractional area covered by the bubbles in each photograph measured. The last column in Table 4 is the estimated contribution of the fission gas bubbles to the total fuel volume change due to irradiation.

The volume change due to fission gas bubble formation in the two S8ER samples examined accounted for approximately $60 \%$ of the observed uncorrected volume change. If it is assumed that rehydriding the fuel to its preirradiation level does not affect the bubble size or density, then a comparison can be made

NAA -SR - 12449 
TABLE 3

FISSION GAS BUBBLE MEASUREMENTS

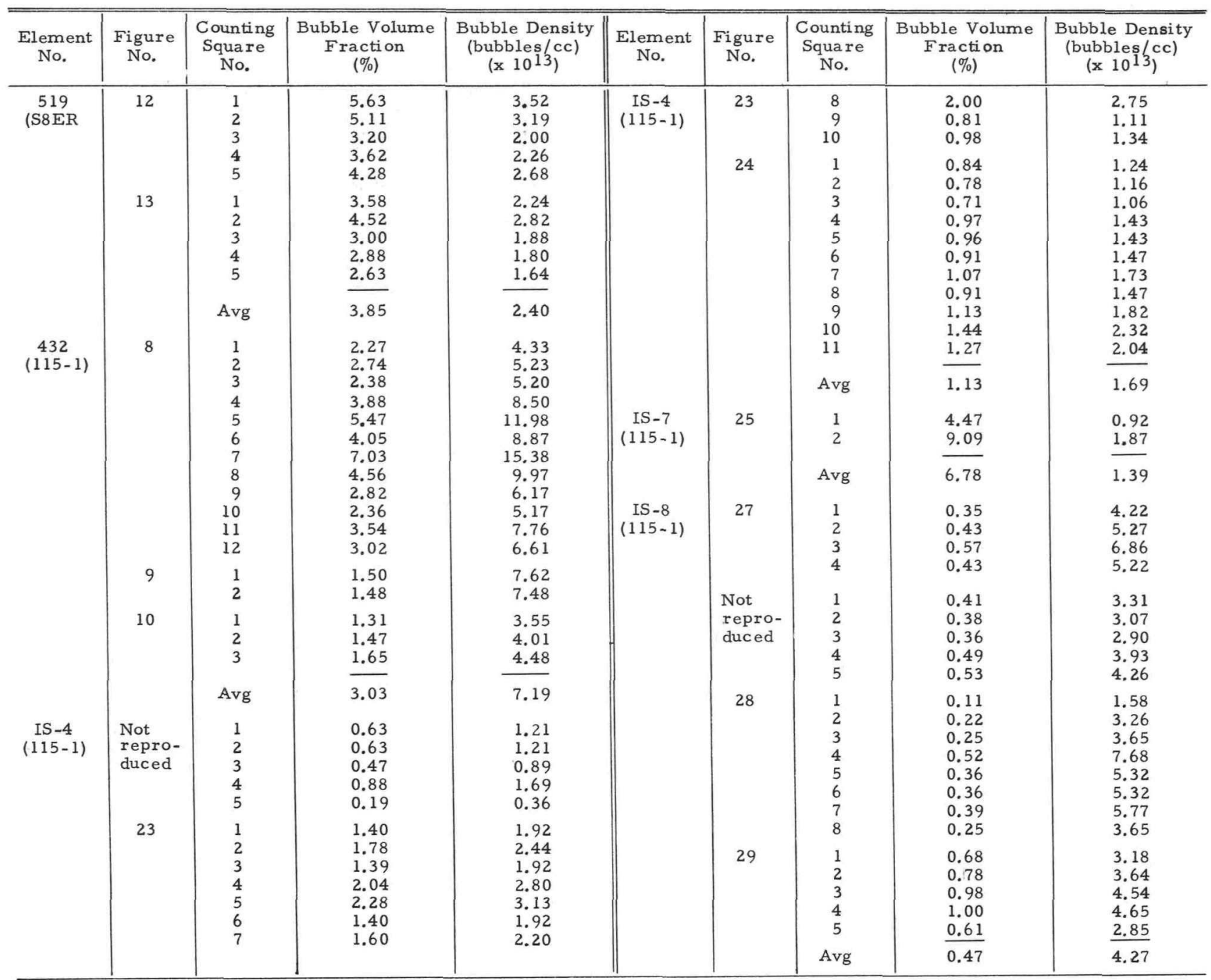


TAB LE 4

VOLUME CHANGE DUE TO FISSION GAS BUBBLE FORMATION

\begin{tabular}{c|c|c|c|c|c}
\hline $\begin{array}{c}\text { Element } \\
\text { No. }\end{array}$ & $\begin{array}{c}\text { Fuel } \Delta \mathrm{V} / \mathrm{V} \\
(\%)\end{array}$ & $\begin{array}{c}\text { Fuel } \Delta \mathrm{V} / \mathrm{V} \\
(\%)\end{array}$ & $\begin{array}{c}\text { Fission Gas } \\
\text { Bubble } \\
\text { Volume } \\
(\%)\end{array}$ & $\begin{array}{c}\text { Estimated } \\
\text { Volume } \\
\text { Corr Factor }\end{array}$ & $\begin{array}{c}\text { Fuel } \Delta \mathrm{V} / \mathrm{V} \\
\text { Due to } \\
\text { Fission Gas } \\
\text { Bubbles } \\
(\%)\end{array}$ \\
\hline 519 & 3.72 & 4.58 & 3.85 & 0.6 & 2.31 \\
432 & 3.94 & 4.25 & 3.03 & 0.7 & 2.12 \\
IS-4 & 4.16 & 4.30 & 1.13 & 0.9 & 1.01 \\
IS-7 & 2.94 & 4.11 & 6.78 & 0.6 & 4.06 \\
IS-8 & 0.74 & 2.08 & 0.47 & 0.9 & 0.42 \\
\hline
\end{tabular}

with the observed hydrogen-corrected volume change. For the two S8ER samples, the fission gas bubbles accounted for approximately $50 \%$ of the hydrogencorrected volume change.

Microcracks observed in the fuel from element 432 may also have added a significant contribution to the fuel swelling.

Based on the measured fuel volume changes in the S8ER samples replicated, the fuel sample examined from element 378 near the top should have revealed microcracks or fission gas bubbles. The measured fuel volume change was greater than either of the 432 or 519 samples. The poor replication results on this sample may not have allowed sufficient resolution to identify the surface features of the fuel. Also, the sample from element 232 which had a large volume change did not give sufficient resolution to detect bubbles.

The contribution of fission gas bubbles to observed hydrogen-corrected volume change in two of the NAA 115-1 fuel specimens examined was less than that observed in the S8ER samples. About 25\% of the observed volume change (uncorrected and corrected) in IS-4 was due to bubble formation. Bubble for mation from IS -8 accounted for $57 \%$ of the uncorrected fuel volume change and only $20 \%$ of the hydrogen-corrected volume change.

The IS-7 data in Table 4 may not be representative of the volume change due to bubble formation. Replication of this sample was poor and only two 
counting squares were obtained from one photograph shown in Figure 25. The bubble population distribution was quite varied, and the counting squares were taken from high bubble density areas to avoid the effects of the bubble depletion zones around large particle sites. Assuming the data are representative, however, it is interesting to note that the volume change due to bubble formation accounted for all of the observed hydrogen-corrected volume change. It is unreasonable to assume that all the volume change was due to bubble formation, but it may have accounted for $80 \%$ of total swelling. This is not unrealistic since IS-7 was believed to have operated in beta phase during irradiation due to high hydrogen loss. (2) This would allow for additional bubble formation with phase change during irradiation.

Annealing studies performed on the fuel from elements 432 and IS-4 have indicated no gross swelling at temperatures up to $1700^{\circ} \mathrm{F}$. Similar studies on IS-7 fuel revealed gross swelling, indicating beta phase fuel annealing characteristics. ${ }^{(8)}$

Length measurements were taken on the distance between large particle sites and the start of the fission gas bubble sites. This was done to determine the width of the bubble depletion zones. Bubble depletion regions on approximately 14 particles were measured on each of seven photographs. The average values and the range of data for each photograph measured are listed in Table 5.

TAB LE 5

BUBBLE DEPLETION ZONE WIDTH MEASUREMENTS ABOUT URANIUM AND CARBIDE PARTICLE SITES

\begin{tabular}{c|c|c|c|c}
\hline $\begin{array}{c}\text { Element } \\
\text { No. }\end{array}$ & $\begin{array}{c}\text { Figure } \\
\text { No. }\end{array}$ & $\begin{array}{c}\text { Number of Particle } \\
\text { Zones Measured }\end{array}$ & $\begin{array}{c}\text { Average } \\
\text { Zone Width } \\
\text { (Microns) }\end{array}$ & $\begin{array}{c}\text { Zone Width } \\
\text { Range } \\
\text { (Microns) }\end{array}$ \\
\hline 519 & 11 & 13 & 0.83 & $0.58-1.22$ \\
432 & 12 & 9 & 1.29 & $0.78-2.07$ \\
& 7 & 26 & 0.57 & $0.33-1.13$ \\
& 9 & 17 & 0.63 & $0.40-1.07$ \\
& 9 & 19 & 0.64 & $0.40-0.87$ \\
\hline
\end{tabular}


Only the S8ER samples were analyzed since the zones observed on the NAA 115-1 samples were not easily defined as to fission gas boundary lines. Depletion zones on the S8ER samples were more easily resolved. The average bubble depletion zone width was 1.07 and 0.61 microns for fuel rods 519 and 432 , respectively.

An average bubble diameter was calculated to be $0.90 \times 10^{-5} \mathrm{~mm}(900 \AA)$ with a range from 0.51 to $1.45 \times 10^{-5} \mathrm{~mm}$ in diameter. An estimate of the relative bubble size in the fuel can be obtained by dividing the average volume fraction due to bubble formation by the average number of bubbles/cc as listed in Table 3. The bubbles in IS-7 were seven times larger than the other NAA 115-1 samples examined. This may indicate a relationship between bubble size and phase or hydrogen content during irradiation.

About ten measurements were taken of the distance between bubbles. These data indicated an average distance of 0.212 microns $\left(2.12 \times 10^{-4} \mathrm{~mm}\right)$ between bubbles.

Measurements were made of the uranium particle density in five of the irradiated samples and the unirradiated fuel to determine if any change occurred due to irradiation. Uranium particle measurements on the unirradiated fuel ranged from $1.1 \times 10^{10}$ to $3.4 \times 10^{11}$ precipitates per cc. Measurements on the three NAA 115-1 fuel samples and elements 432 and 398 from the S8ER fuel indicated a uranium precipitate density ranging from $1.9 \times 10^{10}$ to $1.0 \times 10^{11}$ particles per cc. No measurable decrease in precipitates after irradiation was observed. The order of magnitude of uranium precipitate density found in these samples is in agreement with limited data reported by Taketani ${ }^{(6)}$ from 3 to $6 \times 10^{10}$ particles per cc.

NAA-SR - 12449 


\section{SUMMARY AND CONCLUSIONS}

Resolution of the irradiated $\mathrm{U}-\mathrm{ZrH}$ fuel was generally of high quality and allowed identification of such features as alpha uranium sites, carbide particle sites, phase boundaries, grain boundaries, banding, microcracks, and fission gas bubbles.

Microcracking in the fuel did not appear to be a major contributor to fuel swelling in two of the fuel rods examined from peak distortion areas. Fission gas bubble formation accounted for approximately $50 \%$ of the observed hydrogencorrected volume change in this peak distortion region. Two of the NAA 115-1 fuel specimens with a burnup of $\sim 0.4$ met. at. \% showed a lower percentage contribution of fission gas bubbles to observed volume change than that indicated by the S8ER fuel with a burnup of $\sim 0.2$ met, at. $\%$.

In the S8ER fuel rods examined, no evidence of fission gas bubbles was found in the lower or cooler end of the rods. The peak distortion areas of the rods occurred from 3 to $5 \mathrm{in.}$ from the top in the peak fuel temperature region. Samples with similar postirradiation hydrogen content were taken from peak distortion areas on some rods and the lower end of other rods. This indicates a possible dependence of fission gas bubble size and density on temperature. However, there did not appear to be a correlation with fuel burnup.

Only sample IS-7 gave indication that most of the observed volume change could be attributed to bubble formation. This sample had significantly larger bubbles (although the data are limited) than the other specimens and was believed to have operated in or near beta phase based on annealing studies and postirradiation hydrogen analyses. Hence, there may be a correlation between bubble size and phase. Studies with other irradiated fuels have shown that changes in structural properties through phase change or thermal cycling can affect fuel swelling. (9) Phase change from delta to beta in the U-ZrH system may allow larger bubbles to be formed.

Based on the fuel samples examined, there was no evidence of fission gas bubble sweeping during phase change. No correlation was found between the location of the fission gas bubble sites and epsilon banding or microcracks.

NAA-SR - 12449

64 
Bubble depletion regions observed around large particle sites are thought to be a result of interaction of the gas bubbles with the larger uranium and carbide particles. The bubbles probably exist in this region but are too small to be detected. Similar observations were noted by Kramer et al. ${ }^{(10)}$ in their work on fission gas bubble studies in U-Mo alloys.

Fission gas bubble density measurements on the order of $10^{13}$ bubbles/cc were typical. The average diameter of these bubbles was $900 \AA$ with a mean distance between bubbles of $2.1 \times 10^{-4} \mathrm{~mm}$. 


\section{REFERENCES}

1. K. J. Miller and P. S. Olson, "Post-Operation Evaluation of Fuel Elements from the SNAP 8 Experimental Reactor," NAA-SR-12029 (to be published)

2. P. S. Olson, R. C. Courtright, and R. E. Forrester, "In-Pile Behavior of SNAP 8 Experimental Reactor Type Sublength Fuel Elements (NAA $115-1$ Experiment)," NAA-SR-11996 (November 25, 1966)

3. G. Thomas, Transmission Electron Microscopy of Metals (John Wiley and Sons, Inc., New York, 1962), pp 133-145

4. J. A. Coiley et al., Proceedings of the Fourth International Conference on Electron Microscopy (Springer-Verlap, Berlin, 1960), Section 6, p 440

5. W. E. Krupp and D. D. McAfee, "Metallographic Preparation of Irradiated Zirconium-10 w/o Uranium Alloy Hydride," Advances in Metallography, REP-658 (October 20, 1966), p 43

6. H. Taketani, "Microstructure Studies of SNAP Fuels," NAA-SR-9704 (March 30, 1964)

7. D. Kramer, "Finely Dispersed Phases in Uranium-Molybdenum Ternary Alloys," J. Nuc. Mat. 4, No. 3 (1961), pp 281-286

8. F. C. Schrag, "Annealing Studies on Irradiated SNAP Fuel," NAA-SR-12033 (to be published)

9. G. W. Greenwood et a1., "The Role of Vacancies and Dislocations in the Nucleation and Growth of Gas Bubbles in Irradiated Fissile Material,"

J. Nuc. Mat. 4 (1959), pp 305-324

10. D. Kramer, W. V. Johnston, and C. G. Rhodes, "Reduction of Fission Product Swelling in Uranium Alloys by Means of Finely Dispersed Phases," Journal of Inst. of Metals, Vol 93 (1964-65) pp 145-152 